\title{
Changes in the Ecological Parameters of Mixed Forests of Sal (Shorea robusta Gaertn.) Are a Function of Distance from the Human Settlements
}

\author{
Ramesh P. Sapkota $\mathbb{D}^{1,2}$ Peter D. Stahl, ${ }^{1}$ Krishna Hengaju, ${ }^{2}$ and Kedar Rijal ${ }^{3}$ \\ ${ }^{1}$ Department of Ecosystem Science \& Management and Program in Ecology, University of Wyoming, \\ 1000 E University Avenue, Laramie, WY, USA \\ ${ }^{2}$ Department of Environmental Science, Amrit Campus, Tribhuvan University, Kathmandu, Nepal \\ ${ }^{3}$ Central Department of Environmental Science, Tribhuvan University, Kathmandu, Nepal \\ Correspondence should be addressed to Ramesh P. Sapkota; rsapkota@uwyo.edu
}

Received 17 March 2018; Revised 24 August 2018; Accepted 10 October 2018; Published 30 October 2018

Academic Editor: Ram Chander Sihag

Copyright (C) 2018 Ramesh P. Sapkota et al. This is an open access article distributed under the Creative Commons Attribution License, which permits unrestricted use, distribution, and reproduction in any medium, provided the original work is properly cited.

\begin{abstract}
Forests in Nepal are extremely important for supporting the livelihood of millions of people who collect forest products for their subsistence use and partly for income generation. Such inherent dependence is expected to cause disturbance in the forest ecosystem. We investigated changes in the structural assemblages caused by the interaction between anthropogenic disturbances and forest management activities in the mixed forests of Sal (Shorea robusta Gaertn.) of Terai, Central Nepal. We evaluated three buffer zone community forests (BZCFs), namely, Radha Krishna, Musharni Mai, and Janajagaran of Parsa Wildlife Reserve (PWR); the forest inside PWR was taken as a control. A transect of $2 \mathrm{~km}$ length was laid in each forest, and six plots, each of 1 ha size, were established at a successive interval of $300 \mathrm{~m}$ along the edge to the interior of the forests to count and record the diameter at breast height $(\mathrm{DBH})$ of the studied plants. We observed that the species diversity increased linearly $(\mathrm{p}<0.05)$ towards the forest interior in the BZCFs. Species other than $S$. robusta had significantly higher $(\mathrm{p}<0.05)$ dominance and Importance Value Indices in the interior sites. We did not observe such trends in the control forest. Multivariate analysis showed that the sites of BZCFs had higher structural dissimilarity, but the control forest sites were closer to each other in composition. The forest sites near the settlements had undergone biotic homogenization ( $S$. robusta mixed forest changed to $S$. robusta forest) due to the interaction between anthropogenic disturbances and forest management activities. On the basis of vegetation density, the edges of BZCFs appeared to be protected, but on the basis of diversity failed to do so. Future management strategies should be directed towards enhancing the diversity, heterogeneity, and forest quality, especially near the forest edges.
\end{abstract}

\section{Introduction}

Anthropogenic activities influence the ecological processes [1-3] and have extensive impacts on the forest ecosystems [47]. The fragmentation of natural forests creates a pattern in the landscapes and is regarded as one of the most important causes for the recent decline of forest species [8], and the human activities increase the risk of further degradation in the forests sharing borders with anthropogenic uses [912]. However, with an increasing concern towards forest degradation, management interventions are also underway with a focus on the restoration of degraded areas [13].
Human pressures from the nearby settlements and forest management activities interact to alter the forest structural and functional attributes [14]. Our concern was to determine the extent of such changes in the mixed forest of Sal (Shorea robusta Gaertn.; family: Dipterocarpaceae) of Terai, Central Nepal.

Terai forests of Nepal, dominated by S. robusta, are among the most disturbed ecosystems $[15,16]$. Commonly occurring forests fires every year during dry months also kill young regenerations and burn the deciduous litter layer. In addition, these ecosystems are important for millions of people who depend on forest products for their subsistence 
TABLE 1: List of predominant woody species (species with Importance Value Index > 10) found in the sampling sites and their local uses (all species are used as firewood).

\begin{tabular}{|c|c|c|c|}
\hline Scientific name & Local name & Family & Local uses \\
\hline \multirow{9}{*}{ Shorea robusta Gaertn. } & \multirow{9}{*}{ Sal } & \multirow{9}{*}{ Dipterocarpaceae } & Fodder and animal bedding \\
\hline & & & Religious plant \\
\hline & & & Support for climbers (in gardens) \\
\hline & & & Construction and furniture \\
\hline & & & Handicrafts \\
\hline & & & Cosmetics \\
\hline & & & Seeds (oil) and resin \\
\hline & & & Leaf plates and bowls \\
\hline & & & Medicinal plant \\
\hline \multirow{5}{*}{$\begin{array}{l}\text { Adina cordifolia (Willd. ex Roxb.) } \\
\text { Benth. \& Hook. f. ex Brandis }\end{array}$} & \multirow{5}{*}{ Karam } & \multirow{5}{*}{ Rubiaceae } & Fodder and animal bedding \\
\hline & & & Support for climbers (in gardens) \\
\hline & & & Construction and furniture \\
\hline & & & Handicraft \\
\hline & & & Medicinal plant \\
\hline \multirow{5}{*}{$\begin{array}{l}\text { Lannea coromandelica (Houtt.) } \\
\text { Merr. }\end{array}$} & \multirow{5}{*}{ Jinger } & \multirow{5}{*}{ Anacardiaceae } & Fodder and animal bedding \\
\hline & & & Furniture \\
\hline & & & Medicinal plant \\
\hline & & & Living fences \\
\hline & & & Gum \\
\hline \multirow{5}{*}{ Lagerstroemia parviflora Roxb. } & \multirow{5}{*}{ Botdhayaro } & \multirow{5}{*}{ Lythraceae } & Fodder and animal bedding \\
\hline & & & Support for climbers (in gardens) \\
\hline & & & Construction and furniture \\
\hline & & & Handicrafts \\
\hline & & & Tannins \\
\hline \multirow{2}{*}{ Casearia graveolens Dalzell } & \multirow{2}{*}{ Badkaule } & \multirow{2}{*}{ Flacourtiaceae } & Support for climbers (in gardens) \\
\hline & & & Fruit extract used to poison fish in streams/rivers \\
\hline \multirow{7}{*}{ Cassia fistula L. } & \multirow{7}{*}{ Rajbrikshya } & \multirow{7}{*}{ Fabaceae } & Fruits/legume \\
\hline & & & Veterinary medicine \\
\hline & & & Construction and furniture \\
\hline & & & Handicrafts \\
\hline & & & Medicinal plant \\
\hline & & & Religious plant \\
\hline & & & Ornamental \\
\hline
\end{tabular}

Fodder and animal bedding Support for climbers (in gardens)

Mallotus philippensis (Lam.) Müll.-Arg.

Sindure

Tatari

Dillenia pentagyna Roxb.

Syzygium cumini (L.) Skeels
Jamuna

Myrtaceae
Ornamental

Construction and furniture

Handicrafts

Red dye

Medicinal plant

Animal bedding

Fruits

Religious plant

Vegetables

Medicinal plant

Fodder and animal bedding

$$
\text { Fruits }
$$

Religious plant

Medicinal plant

Support for climbers (in gardens)

Construction and furniture 
TABle 1: Continued.

\begin{tabular}{|c|c|c|c|}
\hline Scientific name & Local name & Family & Local uses \\
\hline Semecarpus anacardium L.f. & Bhalayo & Anacardiaceae & $\begin{array}{c}\text { Fodder and animal bedding } \\
\text { Fruits and nuts } \\
\text { Religious plant } \\
\text { Support for climbers (in gardens) } \\
\text { Medicinal plant }\end{array}$ \\
\hline $\begin{array}{l}\text { Miliusa velutina (Dunal) Hook. f. \& } \\
\text { Thoms. }\end{array}$ & Kalikath & Annonaceae & $\begin{array}{c}\text { Fodder and animal bedding } \\
\text { Fruits } \\
\text { Support for climbers (in gardens) } \\
\text { Construction materials } \\
\text { Handicrafts }\end{array}$ \\
\hline Terminalia alata Heyne ex Roth & Saj & Combretaceae & $\begin{array}{c}\text { Fodder and animal bedding } \\
\text { Construction and furniture } \\
\text { Handicrafts } \\
\text { Seeds } \\
\text { Medicinal plant }\end{array}$ \\
\hline $\begin{array}{l}\text { Cleistocalyx operculatus (Roxb.) } \\
\text { Meer. \& Perry }\end{array}$ & Kyamuna & Myrtaceae & $\begin{array}{c}\text { Fodder and animal bedding } \\
\text { Fruits } \\
\text { Construction } \\
\text { Medicinal plant }\end{array}$ \\
\hline $\begin{array}{l}\text { Anogeissus latifolius (Roxb. ex DC.) } \\
\text { Bedd. }\end{array}$ & Banjhi & Combretaceae & $\begin{array}{c}\text { Fodder and animal bedding } \\
\text { Support for climbers (in gardens) } \\
\text { Construction } \\
\text { Handicrafts } \\
\end{array}$ \\
\hline Terminalia bellirica (Gaertn.) Roxb. & Barro & Combretaceae & $\begin{array}{c}\text { Fodder and animal bedding } \\
\text { Fruits } \\
\text { Construction and furniture } \\
\text { Vegetable oil } \\
\text { Medicinal plant }\end{array}$ \\
\hline Phyllanthus emblica Linn. & Amala & Euphorbiaceae & $\begin{array}{c}\text { Fruits and juice } \\
\text { Religious plant } \\
\text { Medicinal plant } \\
\text { Support for climbers (in gardens) } \\
\text { Construction and furniture } \\
\text { Cosmetics } \\
\text { Seed oil }\end{array}$ \\
\hline Terminalia chebula Retz. & Harro & Combretaceae & $\begin{array}{c}\text { Fodder and animal bedding } \\
\text { Furniture } \\
\text { Fruits } \\
\text { Medicinal plant } \\
\end{array}$ \\
\hline Dalbergia latifolia Roxb. & Satisal & Fabaceae & $\begin{array}{c}\text { Religious plant } \\
\text { Ornamentals } \\
\text { Handicrafts } \\
\text { Construction and furniture } \\
\text { Medicinal plant }\end{array}$ \\
\hline $\begin{array}{l}\text { Desmodium oojenense (Roxb.) } \\
\text { Ohashi }\end{array}$ & Sandan & Fabaceae & $\begin{array}{c}\text { Fodder } \\
\text { Religious plant } \\
\text { Construction and furniture } \\
\text { Handicrafts } \\
\text { Medicinal plant } \\
\end{array}$ \\
\hline Garuga pinnata Roxb. & Dabdabe & Burseraceae & Fodder and animal bedding \\
\hline Buchanania latifolia Roxb. & Piyari & Anacardiaceae & $\begin{array}{c}\text { Fodder and animal bedding } \\
\text { Fruits } \\
\text { Construction and furniture } \\
\text { Handicrafts } \\
\text { Medicinal plant }\end{array}$ \\
\hline
\end{tabular}


TABLE 1: Continued.

\begin{tabular}{|c|c|c|c|}
\hline Scientific name & Local name & Family & Local uses \\
\hline $\begin{array}{l}\text { Dysoxylum gobara (Buch.-Ham.) } \\
\text { Merr. }\end{array}$ & Lasune & Meliaceae & $\begin{array}{c}\text { Fodder and animal bedding } \\
\text { Construction and furniture } \\
\text { Handicrafts } \\
\text { Medicinal plant }\end{array}$ \\
\hline
\end{tabular}

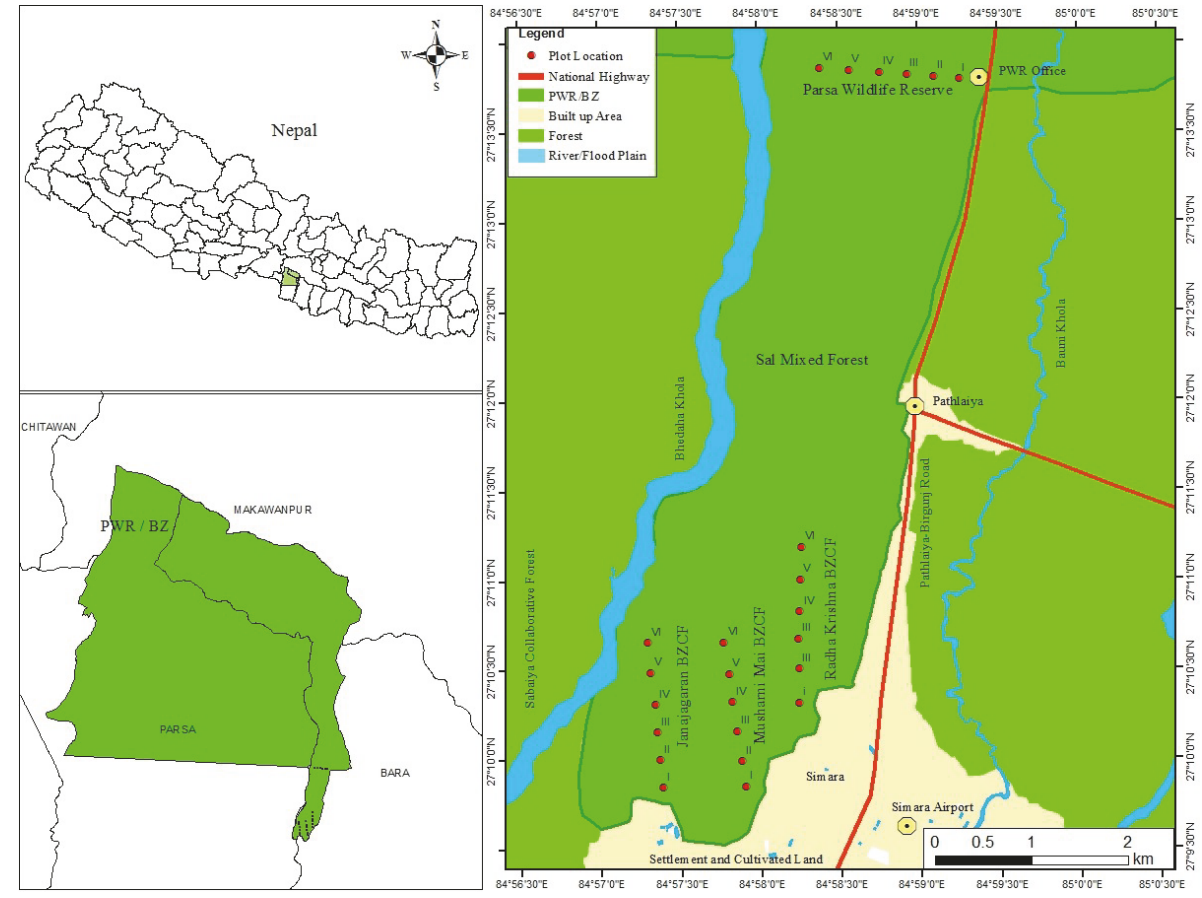

FIGURE 1: Location of studied BZCFs and PWR forest in Bara District, Central Terai, Nepal. In these BZCFs, the forest user groups are different and also vary in a number of households using forest resources. These BZCFs are the southernmost part of a large forest landscape also known as "Charkose Jhadi". People enter from the southern border of the BZCFs to collect/harvest forest resources.

(Table 1). Repeated extraction of forest resources to meet livelihood needs of adjoining human settlements can cause significant impacts on the forest regeneration, structure, and diversity, and these impacts often have been associated with the distance to the settlements [17-20]. In our studied buffer zone community forests (BZCFs), besides harvesting of the forest resources, the forests are also under regular management activities carried by Buffer Zone Management Committees, and the interaction between the disturbances and management interventions might have altered the ecological parameters differently. To our understanding, there are ample studies showing the impacts of forest disturbance on forest structure [16-19], but limited research exists on how management and disturbance interaction influences the composition, structure, richness, and taxonomic diversity of the forests. What ecological changes take place due to such interactions in the forests of Nepal are not known [21].

We attempted to study ecological changes in the Sal forest of Nepal as a result of interaction between inherent disturbances and ongoing management practices (for more than 20 years) in the BZCFs of Nepal. To understand responses of the woody plant species in the forests, our study aimed at elucidating (1) present condition of natural BZCFs in terms of forest community composition, distribution, density, richness, and species diversity as a function of distance from the human settlements, (2) changes in basal area (dominance) of woody species due to management and disturbance interventions from the edge to the forest interior, and (3) effect of anthropogenic disturbances and management interventions on the similarity and dissimilarities of the sites located along the distance from the human settlements. We hypothesized that forest structure differs when management interventions are applied in conjugation with the ongoing disturbances in the forests.

\section{Materials and Methods}

2.1. Study Area. Cross-sectional vegetation survey was conducted in three BZCFs of Parsa Wildlife Reserve (PWR) (PWR has been currently designated as a national park) at Gadimai Municipality, Central Terai Nepal, namely, Janajagaran BZCF (area: 371.10 ha), Musharni Mai BZCF (area: 231.31 ha), and Radha Krishna BZCF (area: 621.171 ha) (Figure 1). The forest in PWR was considered as a control. 


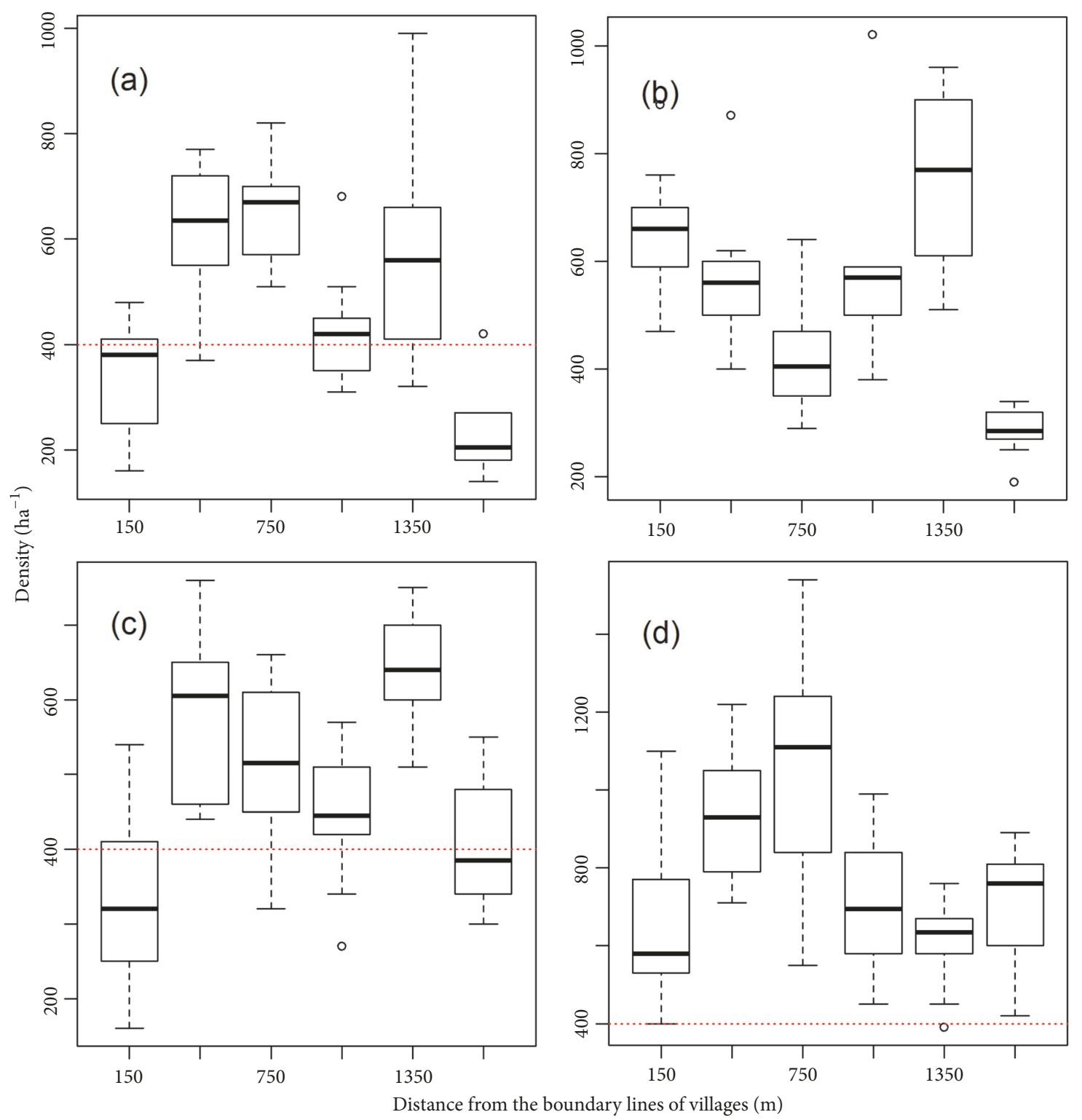

FIGURE 2: Box plot showing total density (stems $\mathrm{ha}^{-1}$ ) of woody plants from the edge to the interior of the forests. (a) Janajagaran BZCF, (b) Musharni Mai BZCF, (c) Radha Krishna BZCF, and (d) Parsa Wildlife Reserve (control forest).

These forests are the part of the largest continuous forest landscape in Terai region, also known as "Charkose Jhadi" in Nepal. The BZCFs are situated in the southern part of PWR (Bhimeshwor BZCF is the other forest located in the southern part of PWR) on alluvial plains and composed of flood or river deposits of sand, silt, clay, coarser sediments, and conglomerates. The BZCFs are adjacent to each other with the connected boundaries between them. Since the forests are connected, the transects laid in the forests were kept at least at the distance of $1.5 \mathrm{~km}$. The area harbors several protected faunal species such as Elephants (Elephas maximus), Royal Bengal Tiger (Panthera tigris), Gauri Gai (Bos gaurus), Wild Dogs (Cannes aurous), and many other common wild animals including spotted deer (Axis axis), barking deer (Muntiacus muntjac), hog deer (Axis porcinus), and wild boar (Sus scrofa). Common reptiles found in the area are golden lizard (Calotes versicolor), monitor lizard (Varanus bengalensis), krait (Bungarus careleus), branded krait (Bungarus faciatus), cobra (Naja naja), and common rat snake (Ptyas mucosus).

The climate in the area is tropical. A typical year can be divided into three main seasons: cold, hot, and rainy. April and May have the highest mean maximum temperature, while the coldest months are November, December, and January. Mean monthly minimum and maximum temperature are $18^{\circ} \mathrm{C}$ and $30^{\circ} \mathrm{C}$, respectively. The average monthly rainfall in the area is $156 \mathrm{~mm}$. Maximum rainfall occurs during the monsoon (June-September) season. 


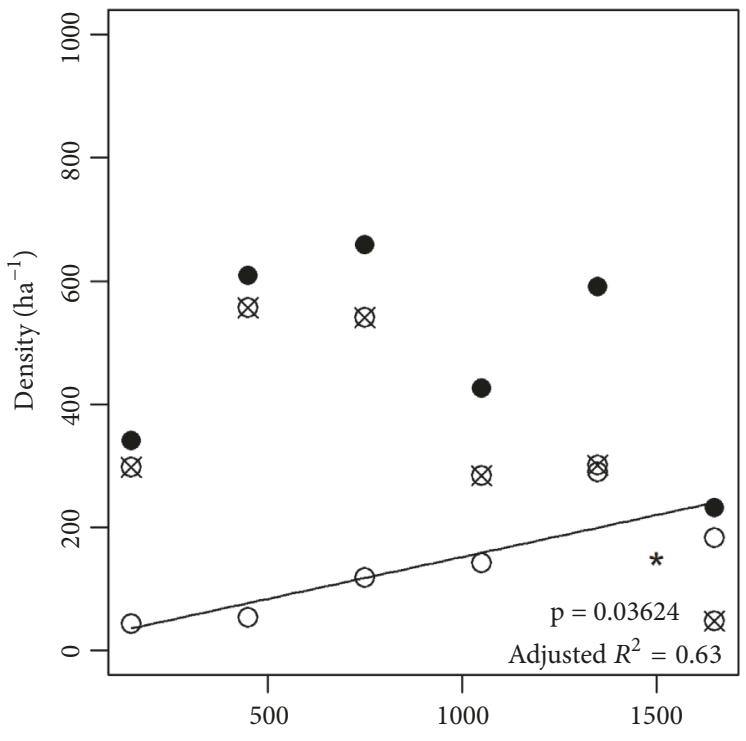

Distance from the boundary lines of villages (m)

(a)

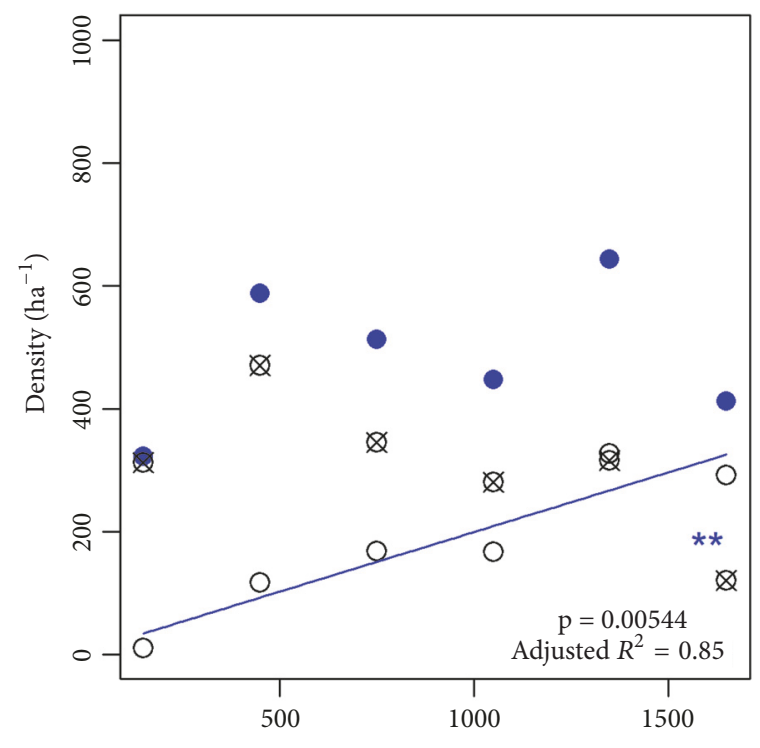

Distance from the boundary lines of villages $(\mathrm{m})$

(c)

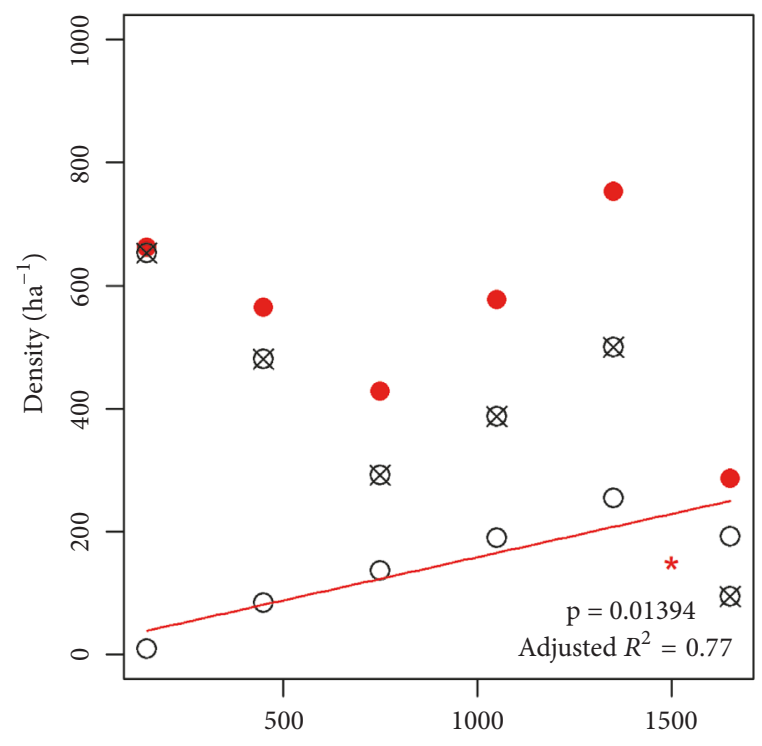

Distance from the boundary lines of villages (m)

(b)

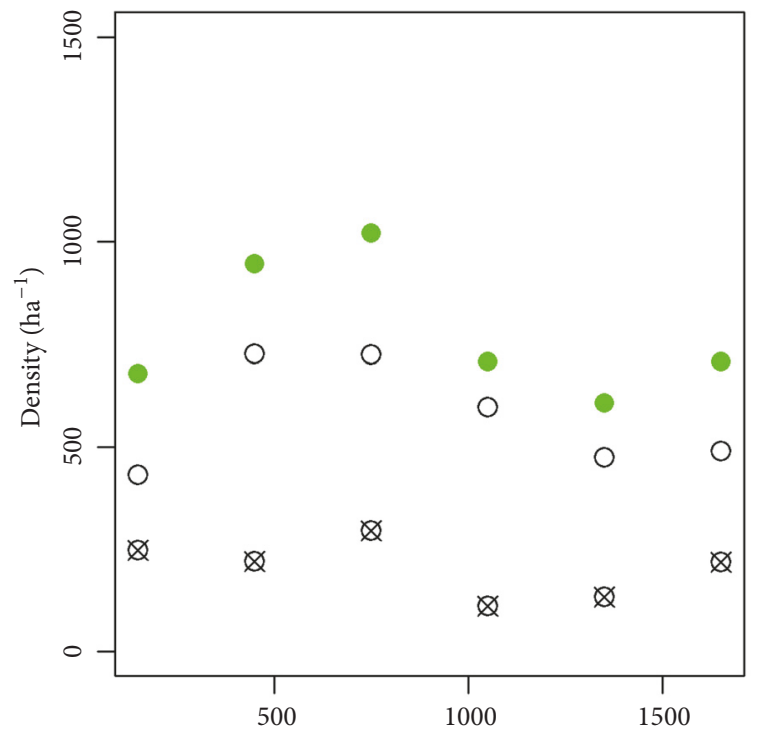

Distance from the boundary lines of villages $(\mathrm{m})$

(d)

FIGURE 3: Density (stems $\mathrm{ha}^{-1}$ ) of woody plant species as a function of distance from the village boundaries. In the figure, solid circles, hollow circles, and circles with crosses denote density of all woody species, density of species other than Shorea robusta, and density of S. robusta, respectively. For the density of stems other than S. robusta, the linear trend was significant for (a) Janajagaran BZCF ( $<<0.05$ ), (b) Musharni Mai BZCF ( $p<0.05)$, and (c) Radha Krishna BZCF ( $<<0.01)$, but the trend was nonsignificant for (d) Parsa Wildlife Reserve ( $p>0.05)$.

2.2. Experimental Design and Sampling. A preliminary survey for the study was carried out during July 2015. Primary data collection and detail inventory of BZCFs and the protected forest inside PWR were carried out from July 2016 to October 2016. Using ArcGIS (10.2.2) and Google Earth Images (Google Earth 7.1.8.3036), an azimuth for each forest was oriented towards the forest interior, away from the corresponding settlement areas. A constant azimuth $\left(355^{\circ}\right.$, $350^{\circ}, 1^{\circ}$, and $275^{\circ}$ for Janajagaran BZCF, Musharni Mai BZCF,
Radha Krishna BZCF, and PWR, respectively) was taken and a transect line was laid along the azimuth (Appendix A, Table 1). Similar sampling design was also adopted in other primary studies $[7,16,17,22]$.

Six plots each of 1 ha size were established on the left side of each transect at a successive interval (horizontal distance) of $300 \mathrm{~m}$ along the edge to the interior of each forest ( $150 \mathrm{~m}$ : Site I, $450 \mathrm{~m}$ : Site II, $750 \mathrm{~m}$ : Site III, $1050 \mathrm{~m}$ : Site IV, $1350 \mathrm{~m}$ : Site V, and $1650 \mathrm{~m}$ : Site VI). The farthest 


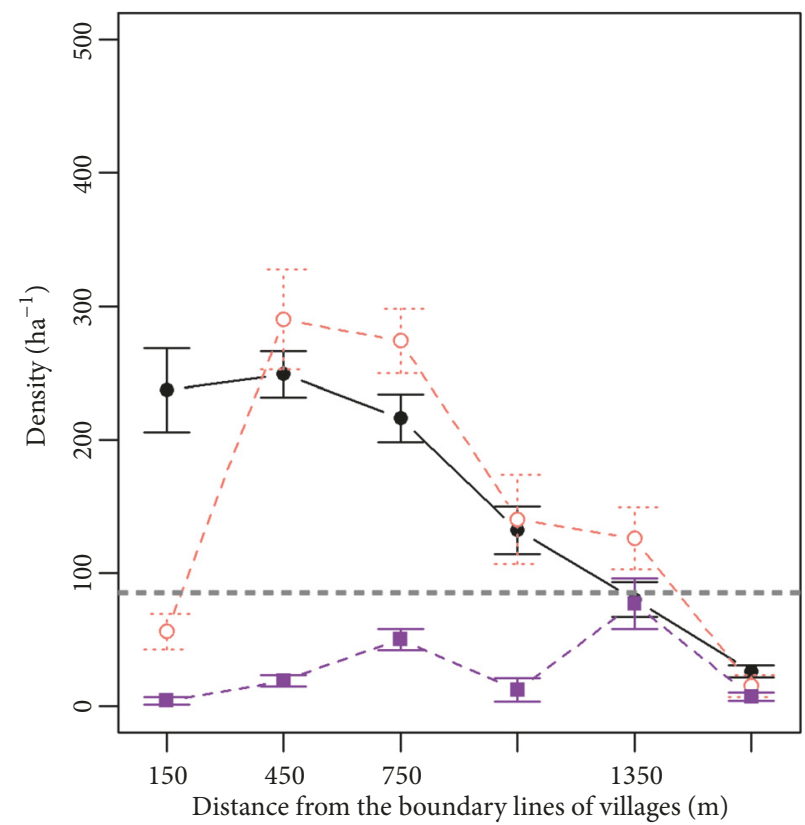

(a)

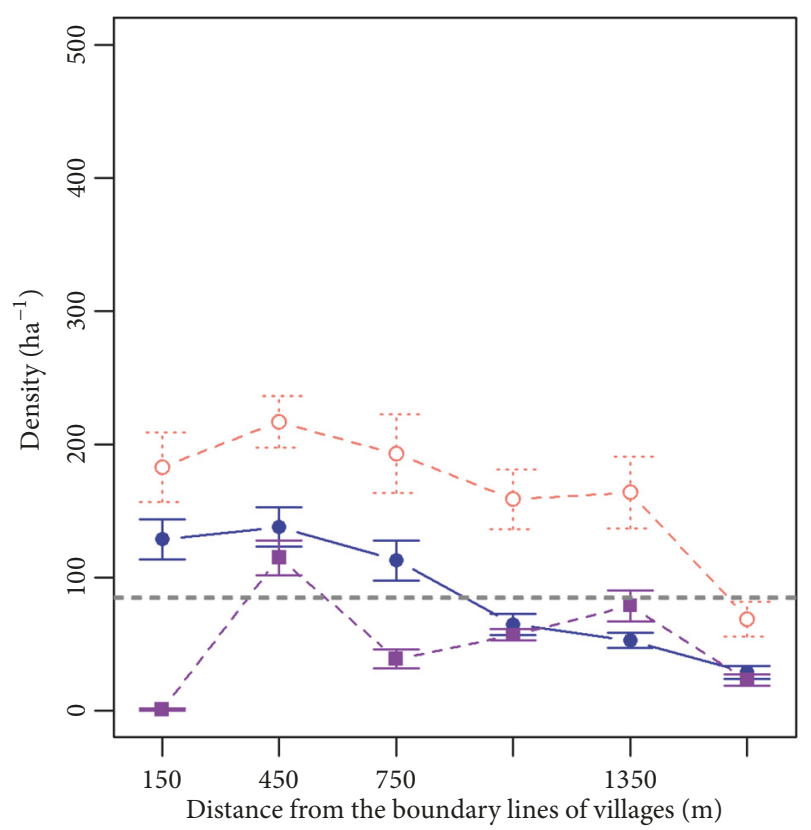

(c)

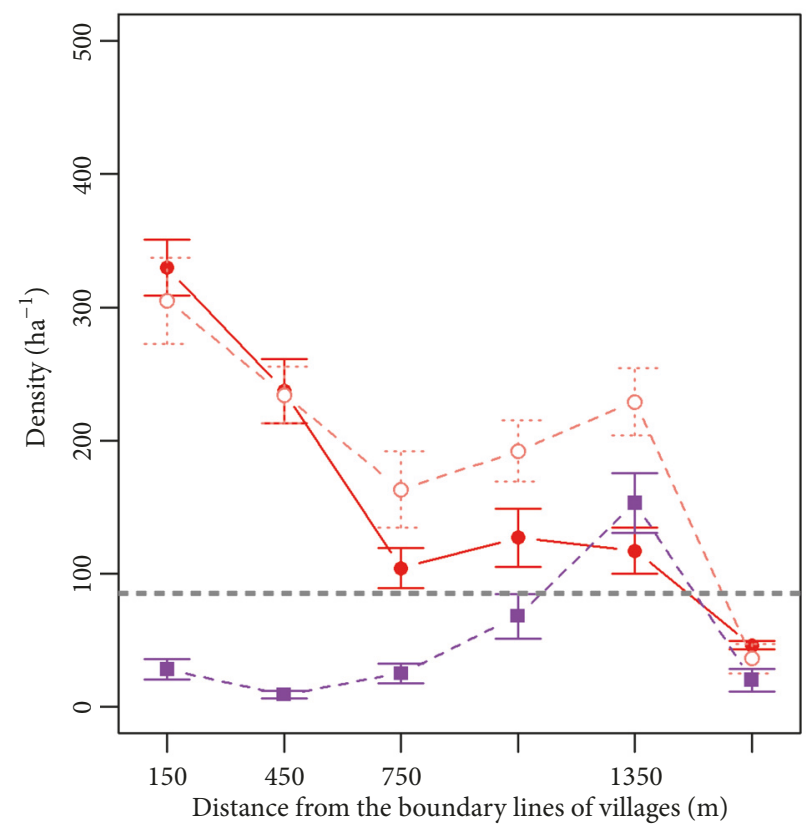

(b)

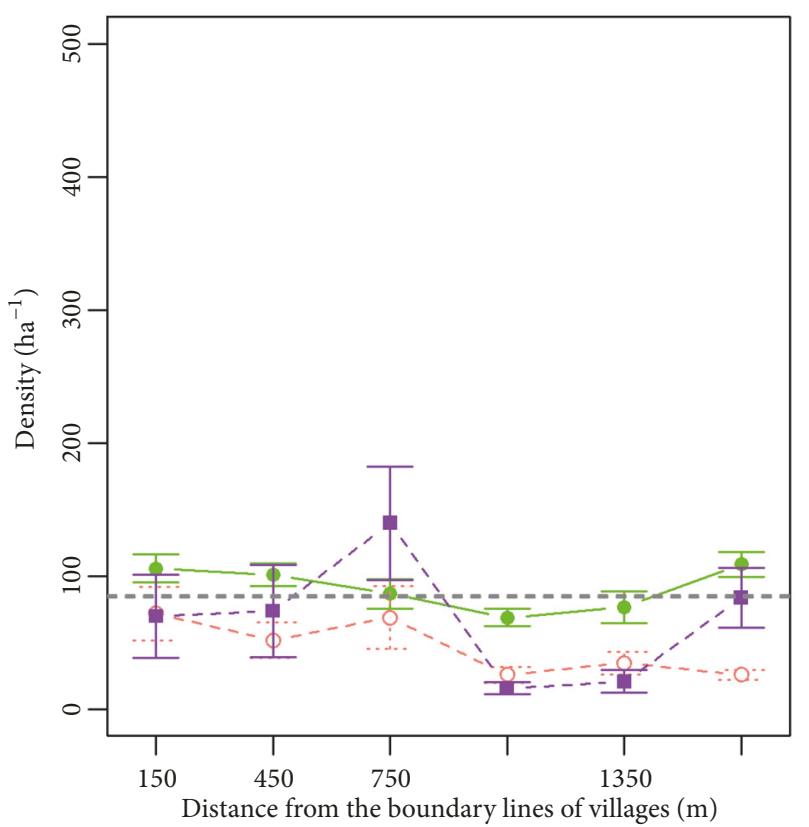

(d)

FIGURE 4: Density (stems ha ${ }^{-1}$ ) of Shorea robusta (categorized as groups under saplings, poles, and trees) plotted against the distance from the village boundary lines. (a) Janajagaran BZCF, (b) Musharni Mai BZCF, (c) Radha Krishna BZCF, and (d) Parsa Wildlife Reserve. Solid lines in the figure indicate the density of the trees. Salmon colored dotted lines show the density of poles, and purple colored dotted lines show the density of saplings. The vertical lines are standard error bars. The horizontal lines are the reference density lines for the maximum number of mature trees $\left(85\right.$ stems ha $\left.^{-1}\right)$ that 1 ha plot can withstand.

distance from the settlement (Site VI) consisted of relatively undisturbed stands (however, there were signs of illegal cutting of some individual stems). For the control forest, a transect was laid starting near the Central Office of PWR along the main entrance (fire line) towards the forest core. We used a handheld GPS (Garmin 60CSx) to determine the position of the plot-centers along the transect line (rope of $100 \mathrm{~m}$ was also stretched to ease transect layout). Each plot was then divided into 10 subplots each of 20 $\times 50 \mathrm{~m}$ for sampling [23]. The total number of sampling units (subplots) was sufficient to produce stabilizing speciesarea curves in the forests (Appendix B, Figure 13). In all 


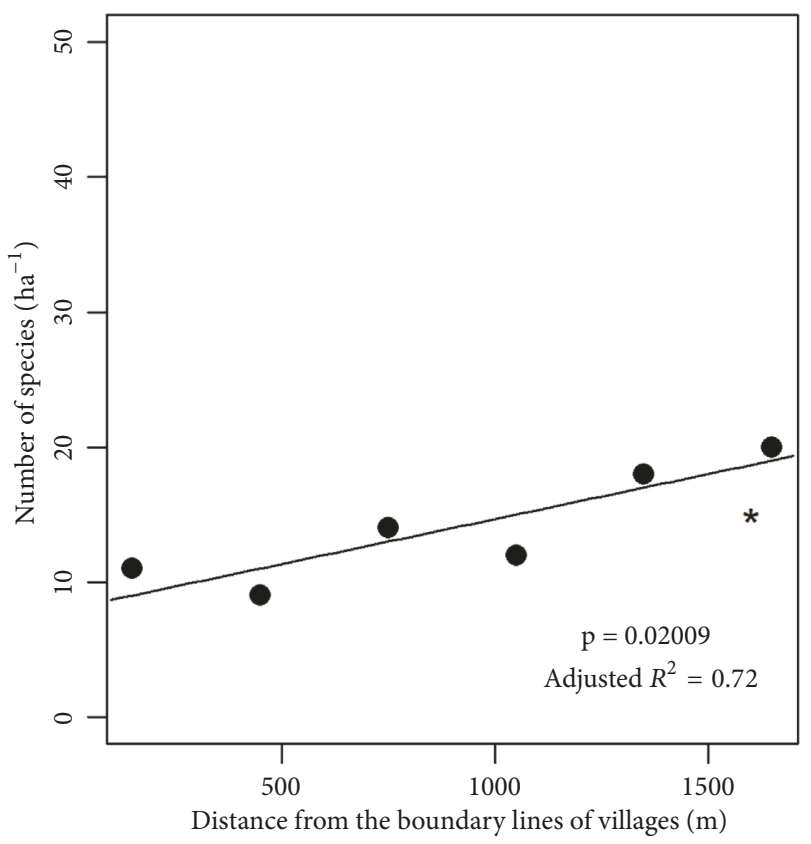

(a)

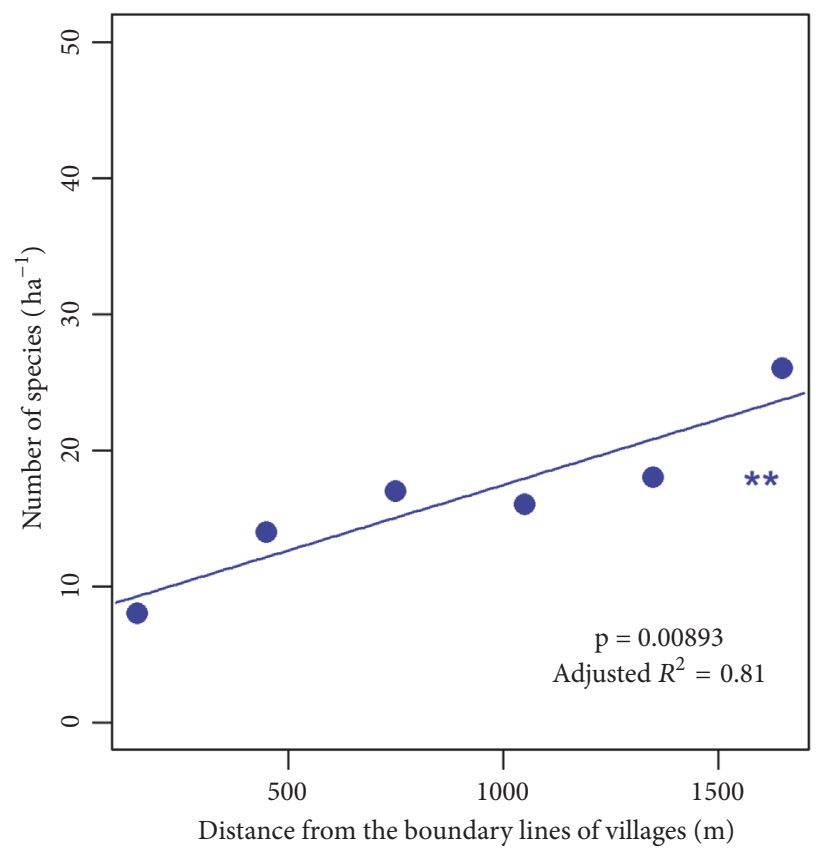

(c)

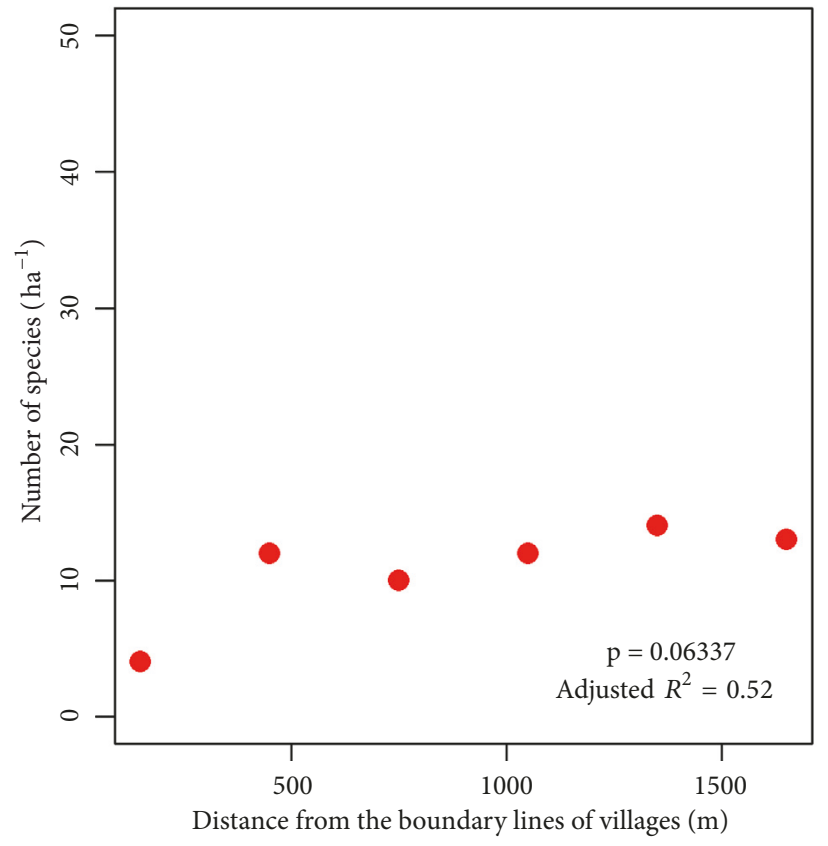

(b)

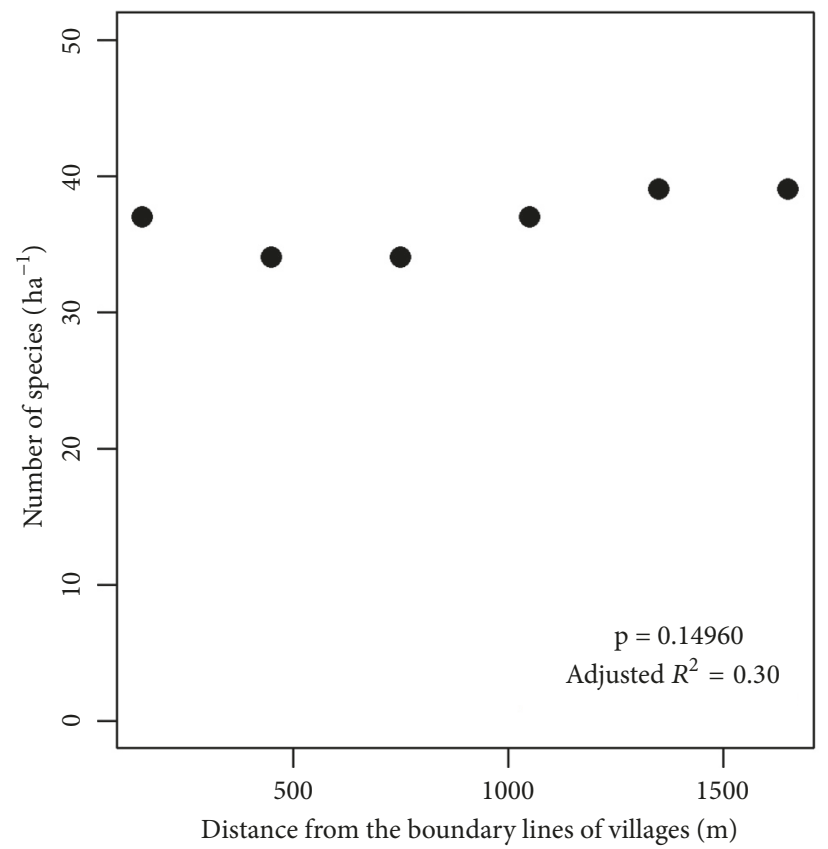

(d)

FIGURE 5: Observed species richness (species $\mathrm{ha}^{-1}$ ) plotted against the distance from the village boundaries. (a) Janajagaran BZCF: significant ( $<$ 0.05), (b) Musharni Mai BZCF: nonsignificant ( $p>0.05)$, (c) Radha Krishna BZCF: significant ( $<<0.01)$, and (d) Parsa Wildlife Reserve: nonsignificant $(\mathrm{p}>0.05)$.

the studied forests, surface fire occurs at least once during the dry season of the year which usually destroys smaller seedlings, so we considered the woody species $\geq 1.5 \mathrm{~cm}$ in diameter at breast height (DBH) which have survived in moderate fire pressure. Structural attributes were collected from a total of 60 subplots in each studied BZCF. The woody species present were identified, counted, and tallied, and
DBH of each individual $\geq 1.5 \mathrm{~cm} \mathrm{DBH}$ was measured at $1.3 \mathrm{~m}$ above the ground with the help of a DBH tape (Kinglon Diameter Tape, Japan). Based on DBH, individuals were classified as saplings (1.5 to $10 \mathrm{~cm} \mathrm{DBH})$, poles $(10$ to $20 \mathrm{~cm}$ $\mathrm{DBH})$, and trees $(>20 \mathrm{~cm} \mathrm{DBH})$. For a multistemmed tree at breast height, it was treated as a single individual whereby the diameters of all stems were measured separately and 


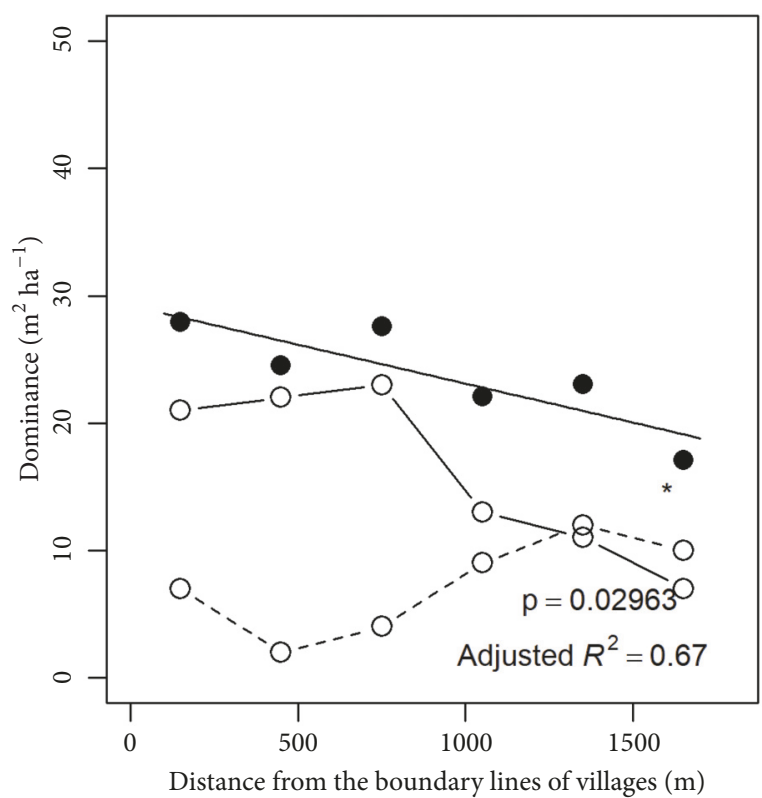

(a)

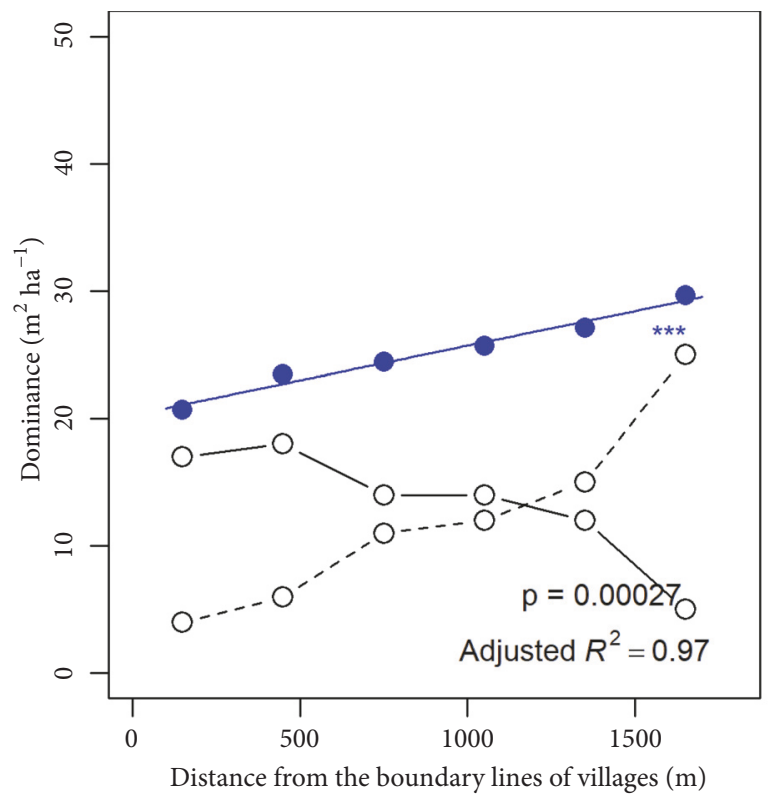

(c)

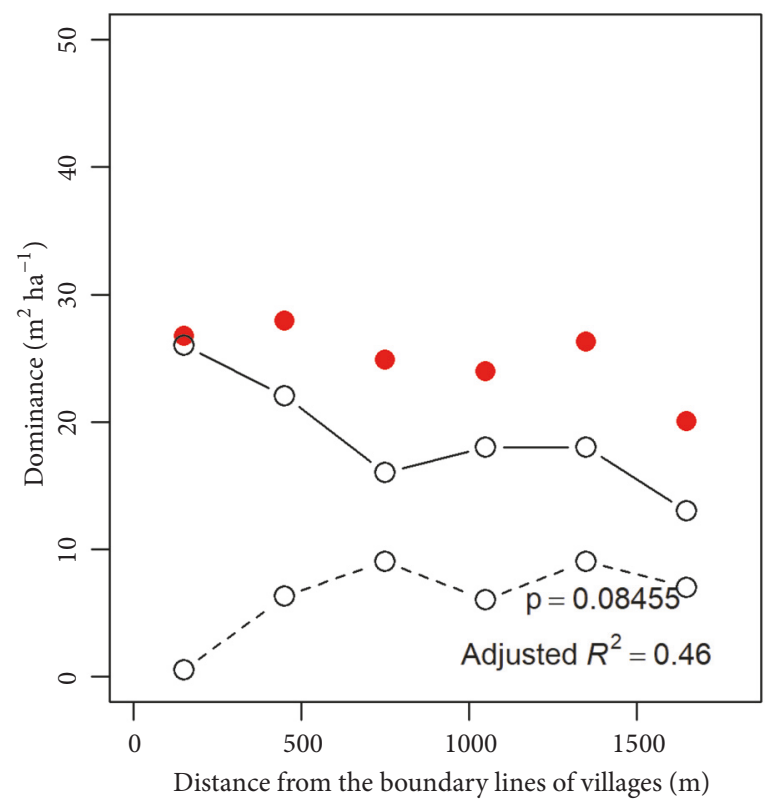

(b)

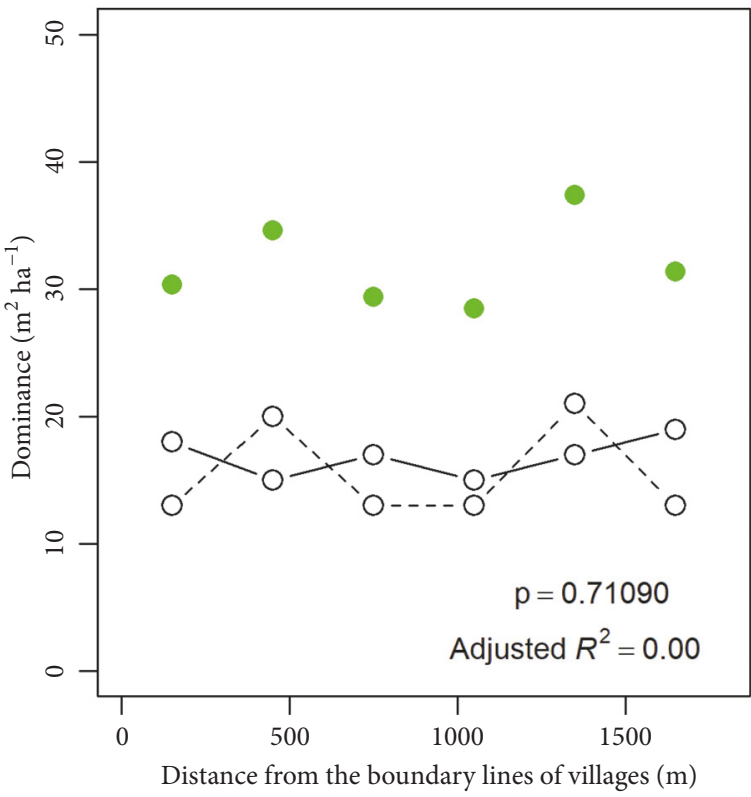

(d)

Figure 6: Dominance (basal area) of species as a function of the distance from the village boundaries. In the figure, solid circles with solid lines, hollow circles with solid lines, and hollow circle with dashed lines indicate total dominance, dominance of Shorea robusta, and dominance of other species except for Shorea robusta, respectively. (a) Janajagaran BZCF: significant ( $<$ 0.05), (b) Musharni Mai BZCF: nonsignificant ( $p$ $>0.05)$, (c) Radha Krishna BZCF: significant ( $<$ 0.001), and (d) Parsa Wildlife Reserve: nonsignificant $(\mathrm{p}>0.05)$.

averaged. In case a tree had a buttress or an abnormality at $1.3 \mathrm{~m}$ height, the diameter was measured just above the abnormality.

Most plants were identified in situ; plants which were not identified to species in the field were identified by the National Herbarium and Plant Laboratories (KATH Herbarium Center) at Godavari, Lalitpur, Nepal (letter reference number 198 2073/2074). The species which could not be identified were considered as "unidentified".

2.3. Data Analysis. Basal area of live woody species (dominance) was calculated as $\Sigma \pi r^{2}$, where $r$ is the radius (DBH/2) for all live woody species with $\mathrm{DBH} \geq 1.5 \mathrm{~cm}$. The density of a 


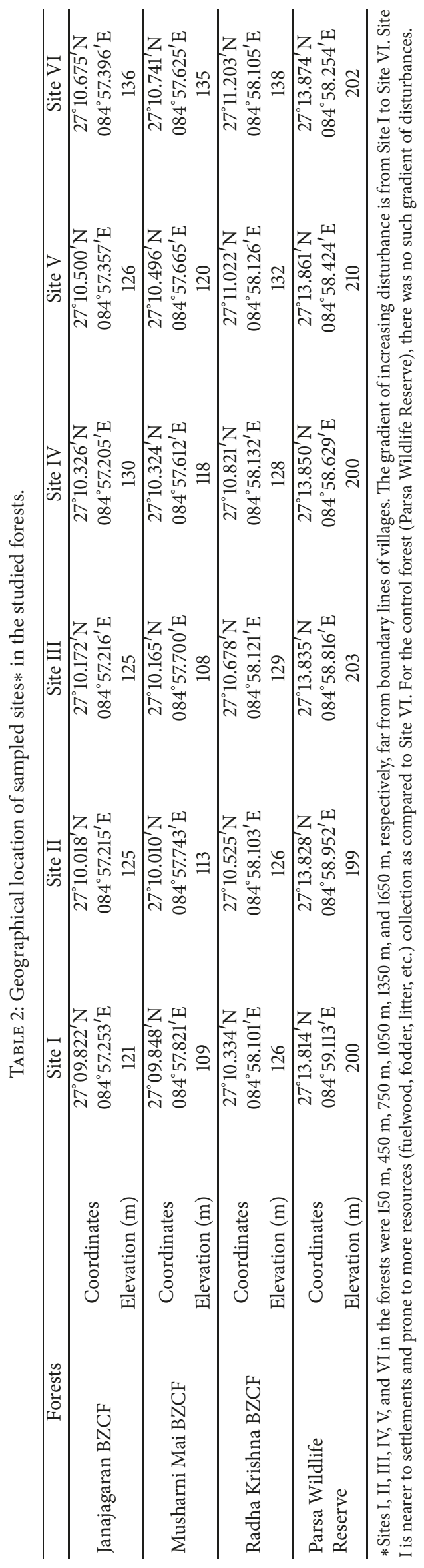




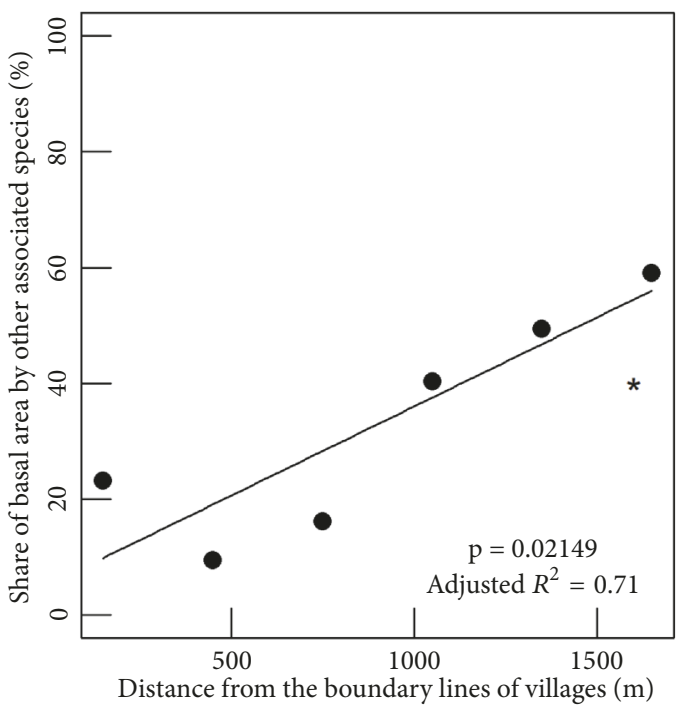

(a)

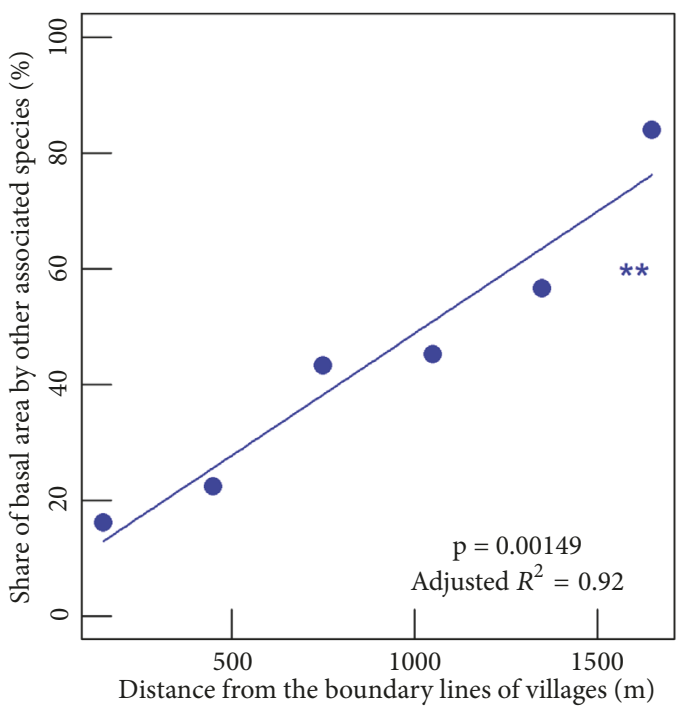

(c)

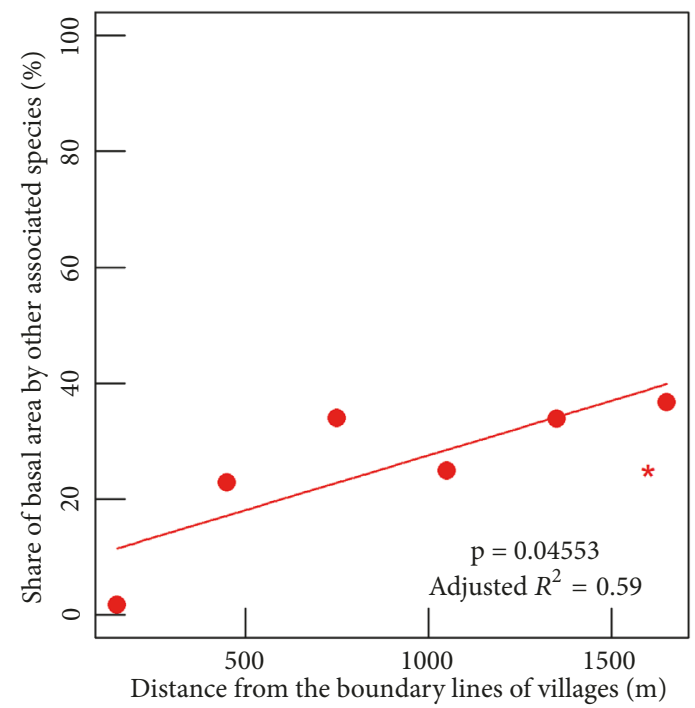

(b)

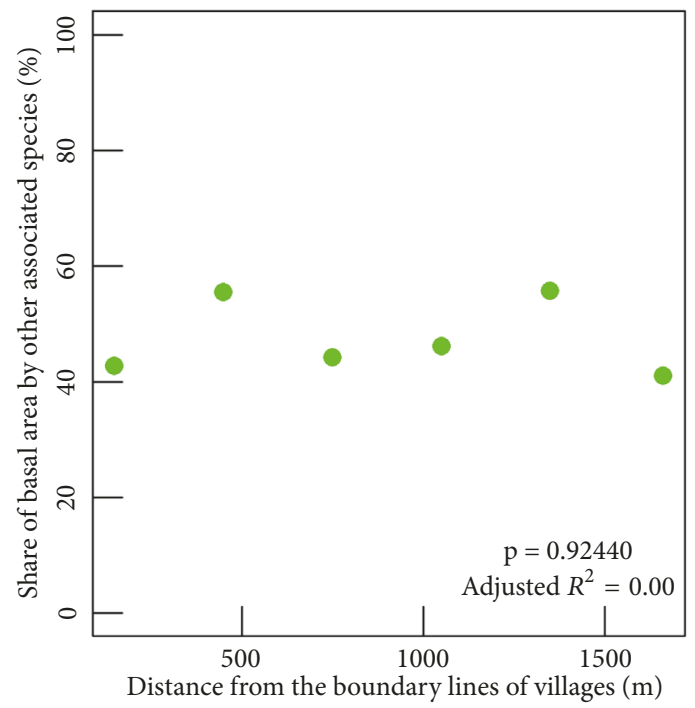

(d)

FIGURE 7: Dominance of species other than Shorea robusta as a function of the distance from the village boundaries. (a) Janajagaran BZCF: significant ( $\mathrm{p}<0.05)$, (b) Musharni Mai BZCF: significant ( $<0.05)$, (c) Radha Krishna BZCF: significant $(\mathrm{p}<0.01)$, and (d) Parsa Wildlife Reserve: nonsignificant $(\mathrm{p}>0.05)$.

TABLE 3: Observed richness, total density, and total basal area along the sites of Janajagaran BZCF.

\begin{tabular}{lcccc}
\hline Site & Observed richness $\left(\mathrm{ha}^{-1}\right)$ & Density \pm SD (individuals ha $\left.{ }^{-1}\right)$ & Basal area $\pm \mathrm{SD}\left(\mathrm{m}^{2} \mathrm{ha}^{-1}\right)$ & Variance of frequency \\
\hline I & 11 & $340 \pm 106.87$ & $27.94 \pm 10.99$ & 761.82 \\
\hline II & 9 & $609 \pm 142.55$ & $24.55 \pm 6.66$ & 1194.44 \\
\hline III & 14 & $658 \pm 97.27$ & $27.61 \pm 1.89$ & 868.13 \\
\hline IV & 12 & $426 \pm 109.16$ & $22.06 \pm 2.69$ & 1456.82 \\
\hline V & 18 & $590 \pm 227.50$ & $23.02 \pm 5.44$ & 1287.91 \\
\hline VI & 20 & $231 \pm 78.94$ & $17.10 \pm 9.92$ & 1231.58 \\
\hline
\end{tabular}




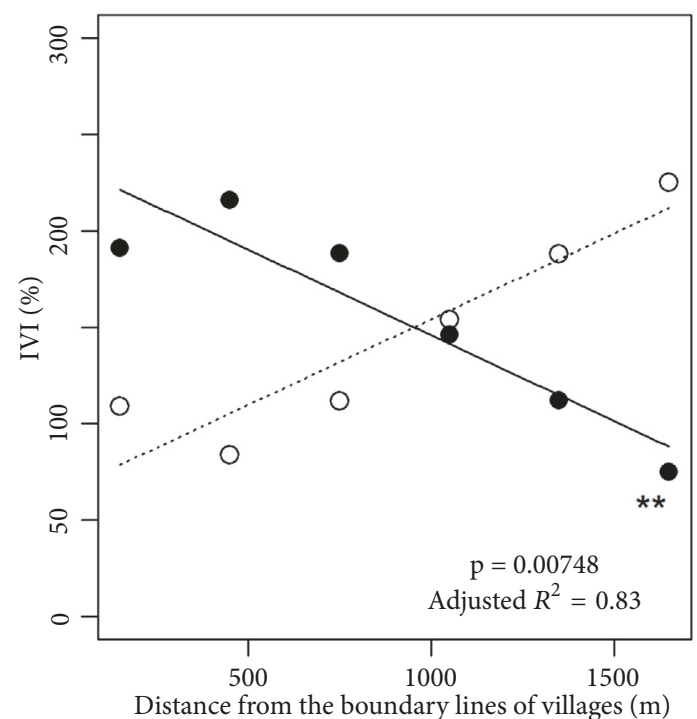

(a)

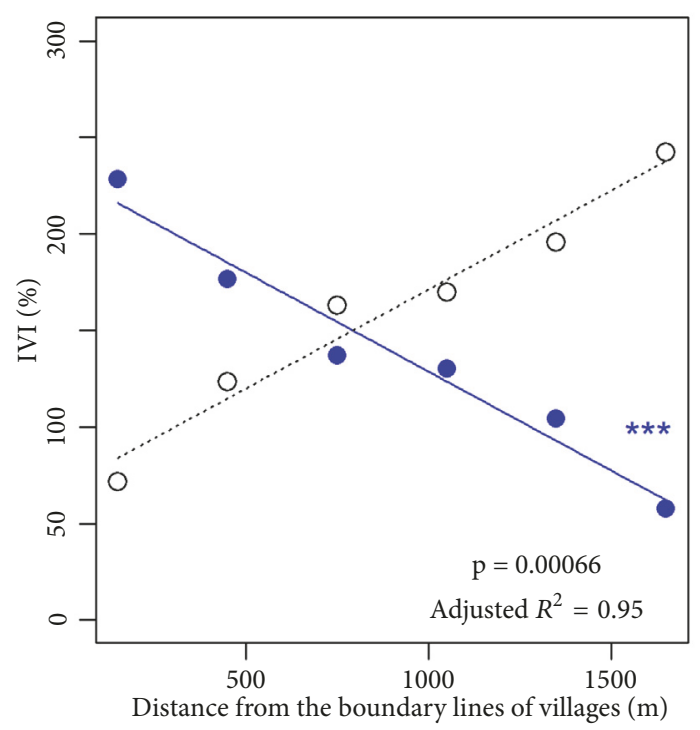

(c)

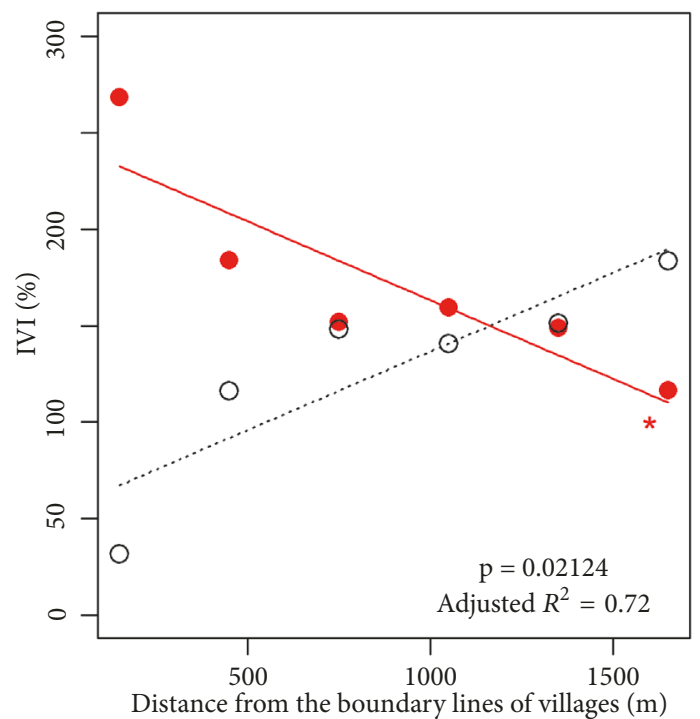

(b)

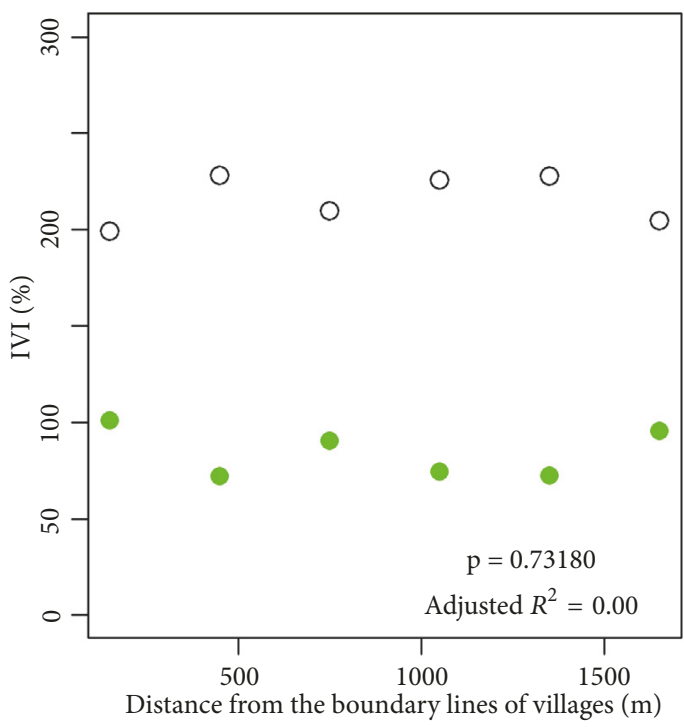

(d)

Figure 8: IVI (\%) as a function of the distance from the village boundaries. (a) Janajagaran BZCF: significant (p < 0.01), (b) Musharni Mai BZCF: significant $(\mathrm{p}<0.05)$, (c) Radha Krishna BZCF: significant $(\mathrm{p}<0.001)$, and (d) Parsa Wildlife Reserve: nonsignificant ( $>0.05)$. The solid lines in the figure indicate IVI (\%) of S. robusta and the dotted lines indicate total IVI (\%) of other species except for $S$. robusta.

TABLE 4: Observed richness, total density, and total basal area along the sites of Musharni Mai BZCF.

\begin{tabular}{|c|c|c|c|c|}
\hline Site & Observed richness $\left(\mathrm{ha}^{-1}\right)$ & Density \pm SD (individuals ha $^{-1}$ ) & Basal area $\pm S D\left(\mathrm{~m}^{2} \mathrm{ha}^{-1}\right)$ & Variance of frequency \\
\hline I & 4 & $662 \pm 113.12$ & $26.73 \pm 5.53$ & 1900 \\
\hline II & 12 & $564 \pm 131.17$ & $27.92 \pm 7.70$ & 953.79 \\
\hline III & 10 & $428 \pm 109.52$ & $24.87 \pm 6.11$ & 1262.22 \\
\hline IV & 12 & $577 \pm 169.84$ & $23.94 \pm 6.74$ & 1384.09 \\
\hline $\mathrm{V}$ & 14 & $753 \pm 158.47$ & $26.29 \pm 4.42$ & 1241.76 \\
\hline VI & 13 & $286 \pm 45.019$ & $20.03 \pm 6.52$ & 1560.26 \\
\hline
\end{tabular}




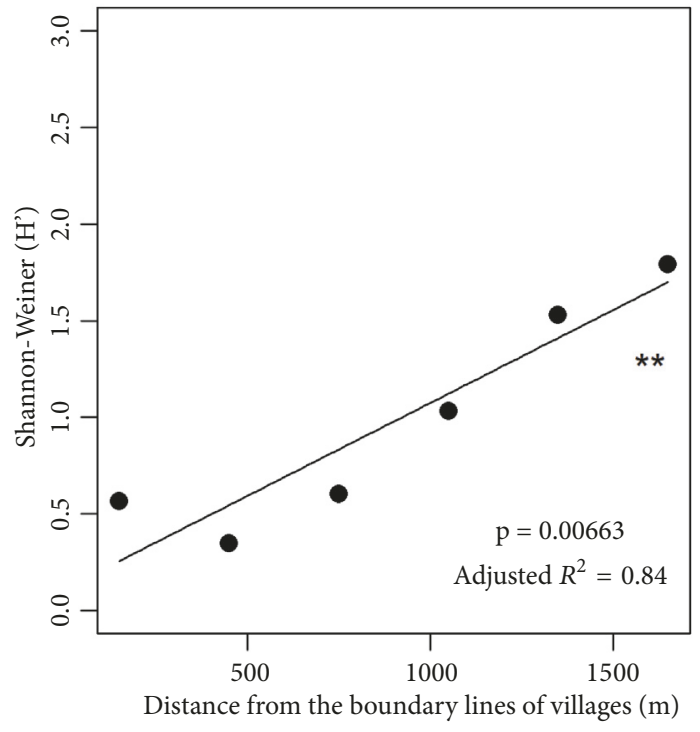

(a)

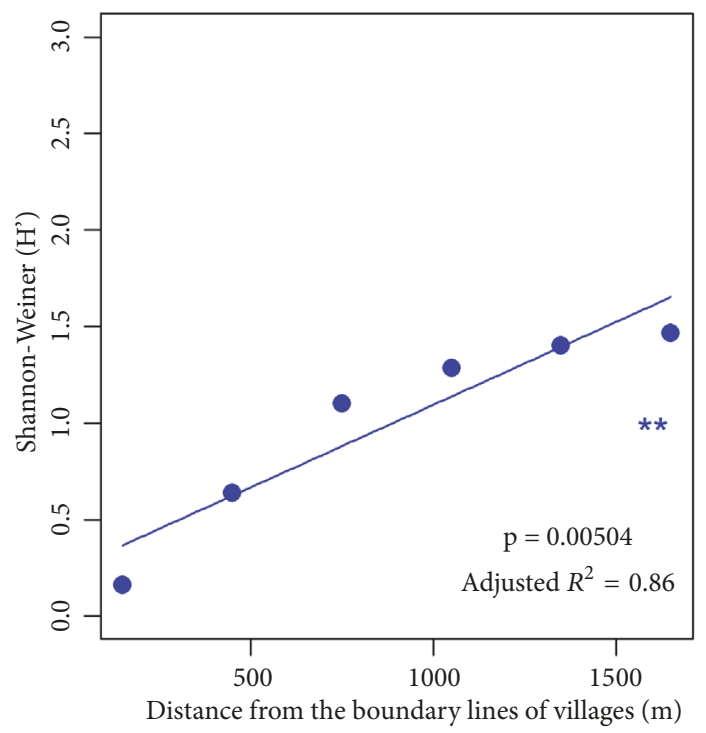

(c)

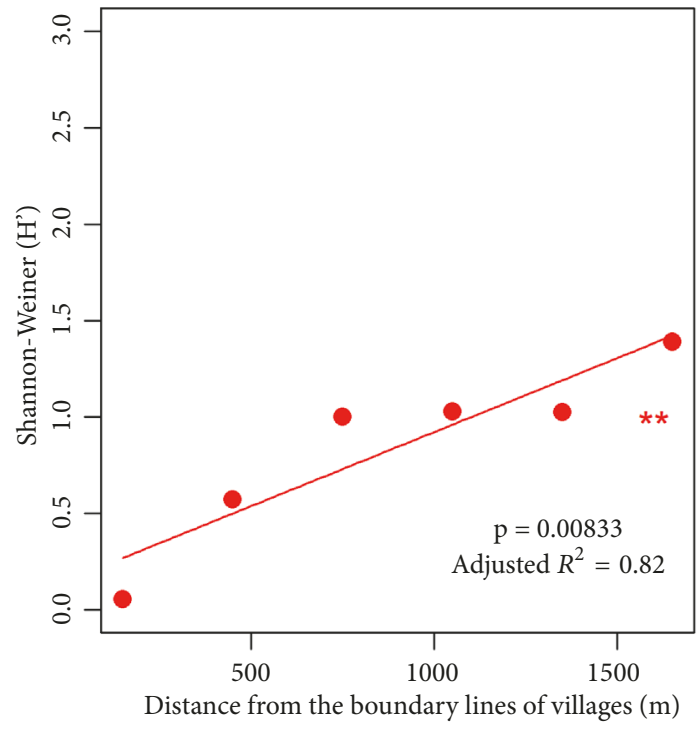

(b)

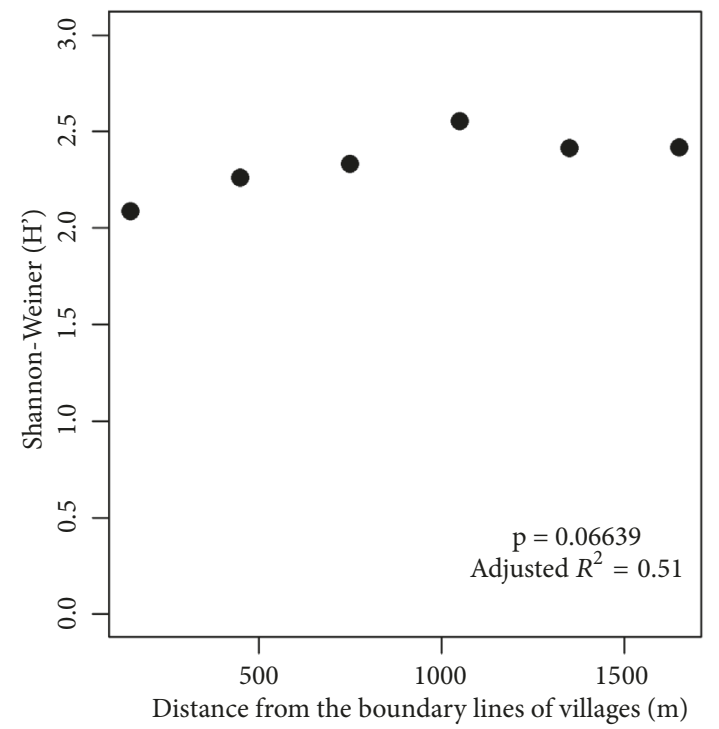

(d)

FigurE 9: Shannon-Wiener H' diversity index as a function of the distance from the village boundaries. (a) Janajagaran Forest: significant ( $p<0.01$ ), (b) Musharni Mai Forest: significant ( $<<0.01)$, (c) Radha Krishna Forest: significant $(\mathrm{p}<0.01)$, and (d) Parsa Wildlife Reserve: nonsignificant $(\mathrm{p}>0.05)$.

TABLE 5: Observed richness, total density, and total basal area along the sites of Radha Krishna BZCF.

\begin{tabular}{|c|c|c|c|c|}
\hline Site & Observed richness $\left(\mathrm{ha}^{-1}\right)$ & Density \pm SD (individuals ha ${ }^{-1}$ ) & Basal area \pm SD $\left(\mathrm{m}^{2} \mathrm{ha}^{-1}\right)$ & Variance of frequency \\
\hline $\mathrm{I}$ & 8 & $323 \pm 112.16$ & $20.69 \pm 6.74$ & 942.86 \\
\hline II & 14 & $587 \pm 110.66$ & $23.46 \pm 4.53$ & 965.39 \\
\hline III & 17 & $513 \pm 107.61$ & $24.44 \pm 4.25$ & 1127.94 \\
\hline IV & 16 & $448 \pm 93.07$ & $25.67 \pm 6.00$ & 1179.58 \\
\hline $\mathrm{V}$ & 18 & $643 \pm 71.81$ & $27.09 \pm 6.86$ & 1379.41 \\
\hline$\overline{\mathrm{VI}}$ & 26 & $413 \pm 89.20$ & $29.68 \pm 10.50$ & 877.54 \\
\hline
\end{tabular}




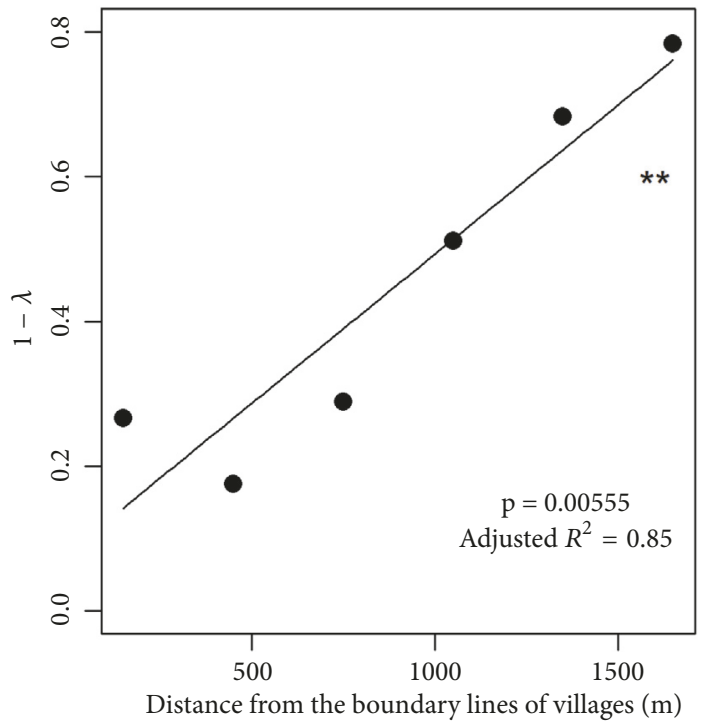

(a)

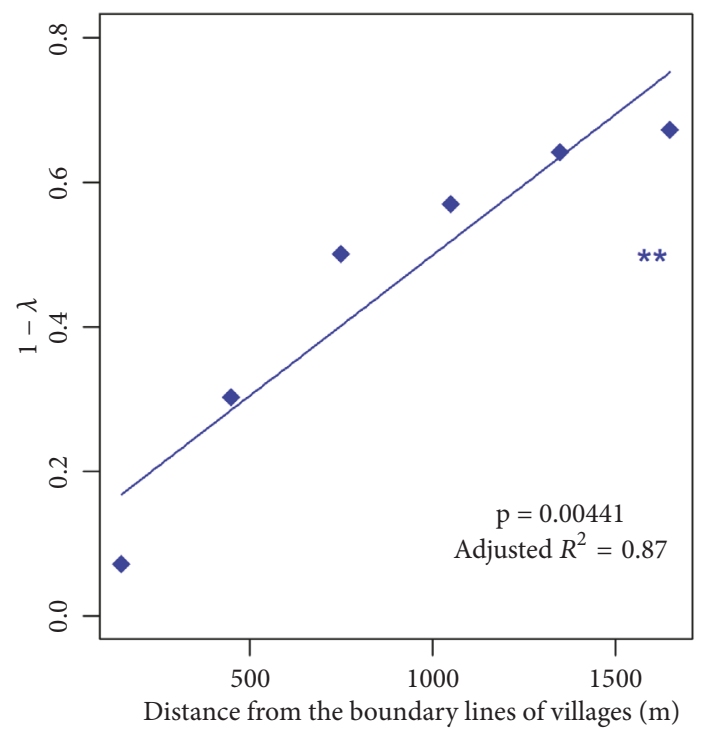

(c)

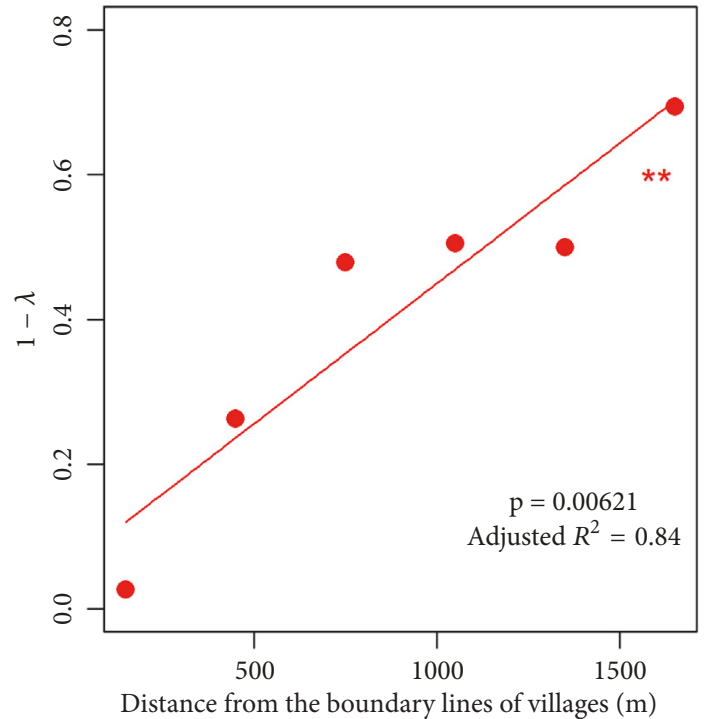

(b)

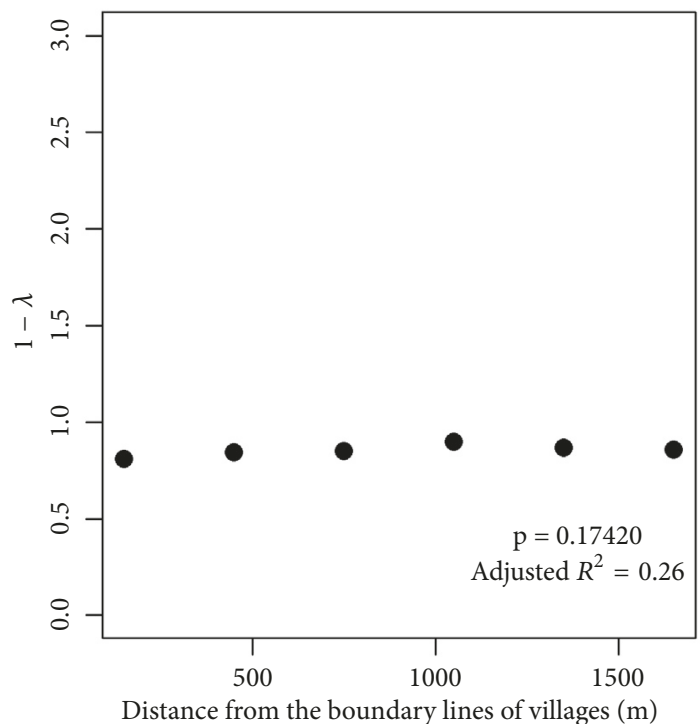

(d)

FIgURE 10: 1 - Simpson's $\lambda\left(1-\sum \mathrm{pi}^{2}\right)$ plotted against the distance from the village boundaries. (a) Janajagaran Forest: significant ( $\left.\mathrm{p}<0.01\right),(\mathrm{b})$ Musharni Mai Forest: significant ( $\mathrm{p}<0.01$ ), (c) Radha Krishna Forest: significant $(\mathrm{p}<0.01$ ), and (d) Parsa Wildlife Reserve: nonsignificant ( $\mathrm{p}$ $>0.05)$.

TABLE 6: Observed richness, total density, and total basal area along the sites of Parsa Wildlife Reserve.

\begin{tabular}{lcccc}
\hline Site & Observed richness $\left(\mathrm{ha}^{-1}\right)$ & Density \pm SD (individuals ha $\left.{ }^{-1}\right)$ & Basal area \pm SD $\left(\mathrm{m}^{2}\right.$ ha $\left.^{-1}\right)$ & Variance of frequency \\
\hline I & 37 & $679 \pm 250.31$ & $30.34 \pm 6.42$ & 1001.87 \\
\hline II & 34 & $946 \pm 182.04$ & $34.59 \pm 9.71$ & 1208.91 \\
\hline III & 34 & $1021 \pm 311.43$ & $29.40 \pm 6.18$ & 1109.80 \\
\hline IV & 37 & $707 \pm 160.56$ & $28.46 \pm 8.19$ & 1091.59 \\
\hline V & 39 & $607 \pm 112.45$ & $37.38 \pm 8.60$ & 968.15 \\
\hline VI & 39 & $708 \pm 139.43$ & $31.34 \pm 6.61$ & 960.46 \\
\hline
\end{tabular}




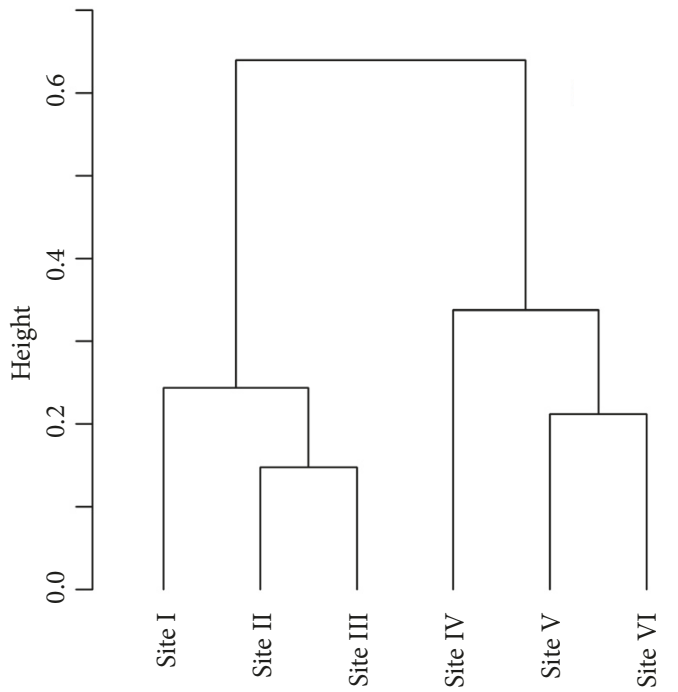

(a)

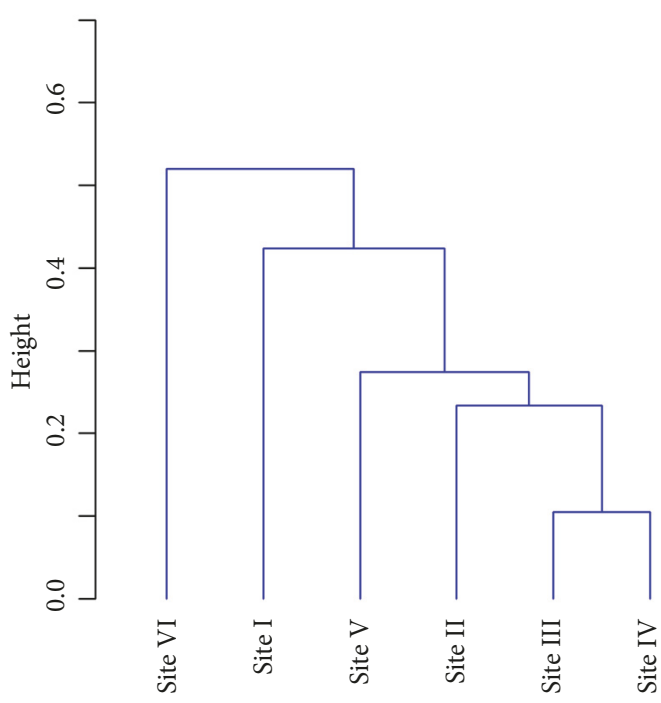

(c)

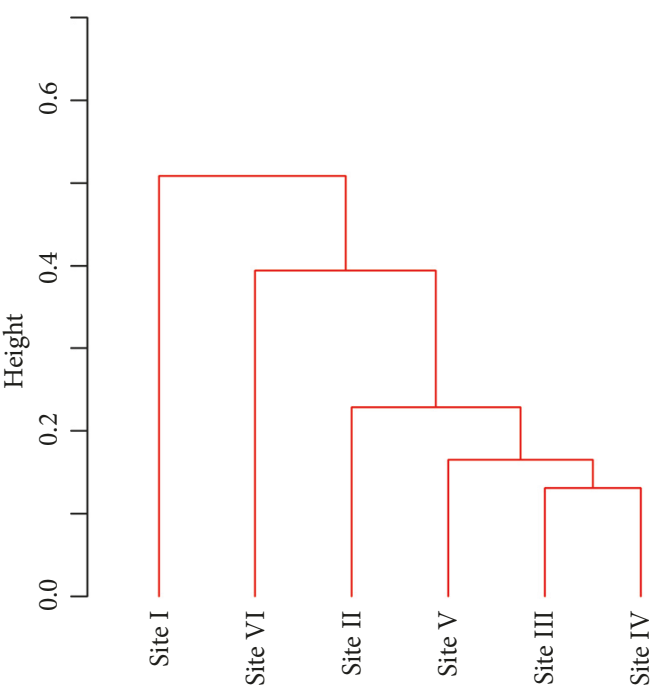

(b)

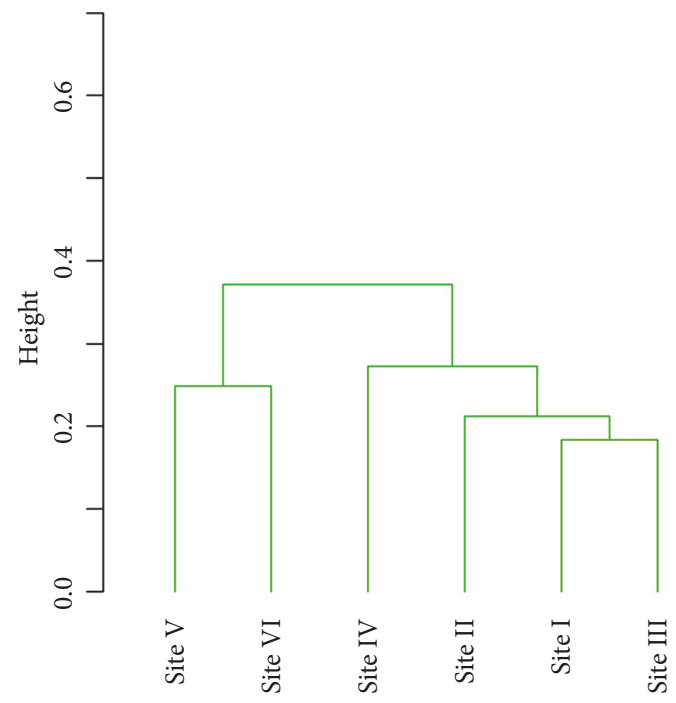

(d)

FIGURE 11: Multivariate agglomerative clustering (Ward D.2 group linkage) based on Bray-Curtis distance (species IVI dissimilarities) between the studied sites. (a) Janajagaran BZCF, (b) Musharni Mai BZCF, (c) Radha Krishna BZCF, and (d) Parsa Wildlife Reserve.

species was calculated as the number of individuals of species per unit area. Similarly, the estimated maximum density of mature $S$. robusta trees that 1 ha forest area can support was calculated with the mean value of the area covered by canopy projections of mature trees in natural growth conditions and considering that there will be no overlap of canopy between individuals of the species. The canopy projections (length) over cardinal and ordinal directions were measured based on the observation made vertically upwards and recorded as to whether or not the canopy of the trees obscures the sky [24]. The canopy cover area was calculated based on horizontal projections data and using readWKT and gArea functions in the rgeos package [25] and then was compared with 1 ha area.

The Importance Value Index (IVI) for each woody species was determined to evaluate the contribution of woody species in the forest composition, structure, and biomass. The IVI for a species was calculated by summing the relative frequency, relative density, and relative dominance [26-28]:

$$
\operatorname{IVI}_{j}=100\left(\frac{n_{j}}{N}+\frac{d_{j}}{D}+\frac{x_{j}}{X}\right)
$$

where $\mathrm{IVI}_{j}$ is the importance value of the $\mathrm{jth}$ species, $n_{j}$ is the frequency of $\mathrm{jth}$ species, $\mathrm{N}$ is the sum of frequencies $(\mathrm{N}$ $\left.=\sum n_{j}\right), d_{j}$ is the number of individuals of the $j$ th species present in the sample population, $\mathrm{D}$ is the total number of individuals in the sample population $\left(D=\sum d_{j}\right), x_{j}$ is the sum of dominance for the jth species, and $\mathrm{X}$ is the total dominance across all species $\mathrm{X}=\sum \mathrm{X}_{\mathrm{j}}$. Since relative frequency, relative density, and relative dominance are expressed in percentage, the maximum value of IVI is equal to 300 . 


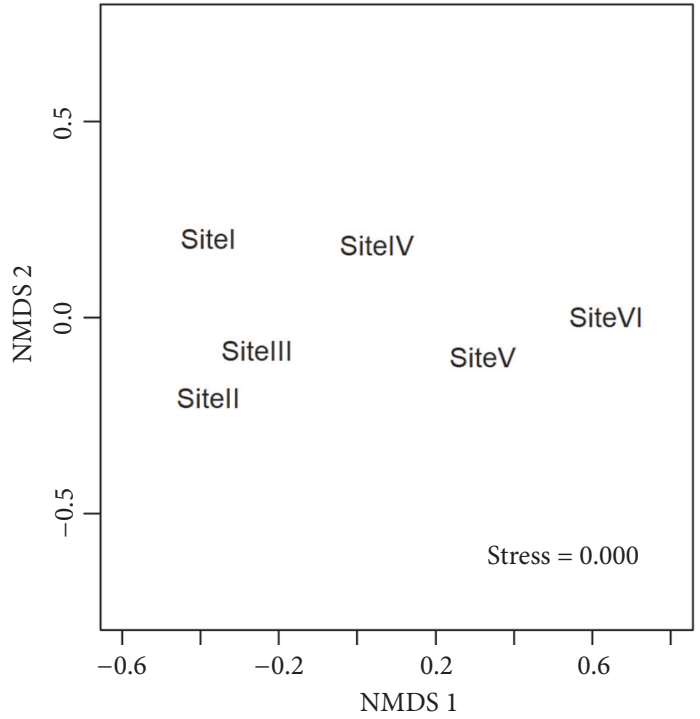

(a)

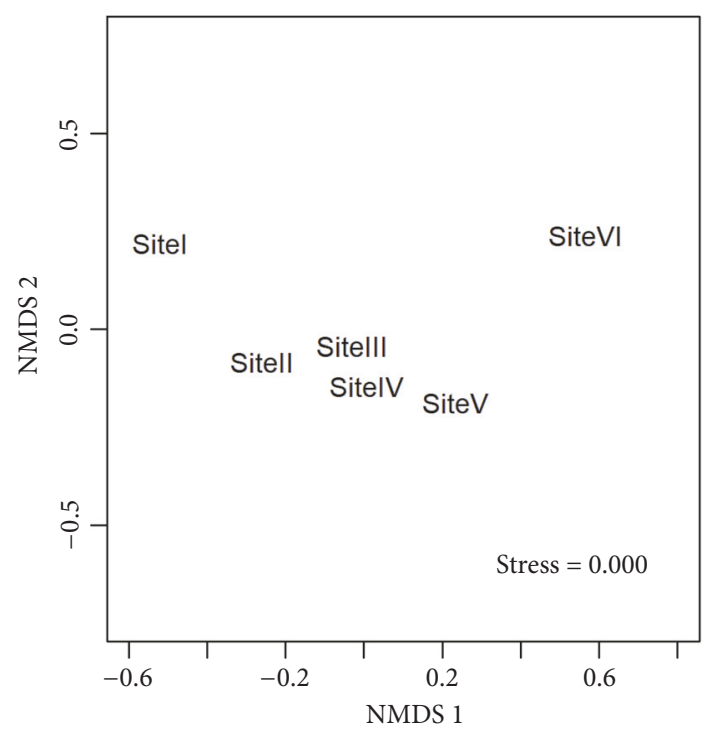

(c)

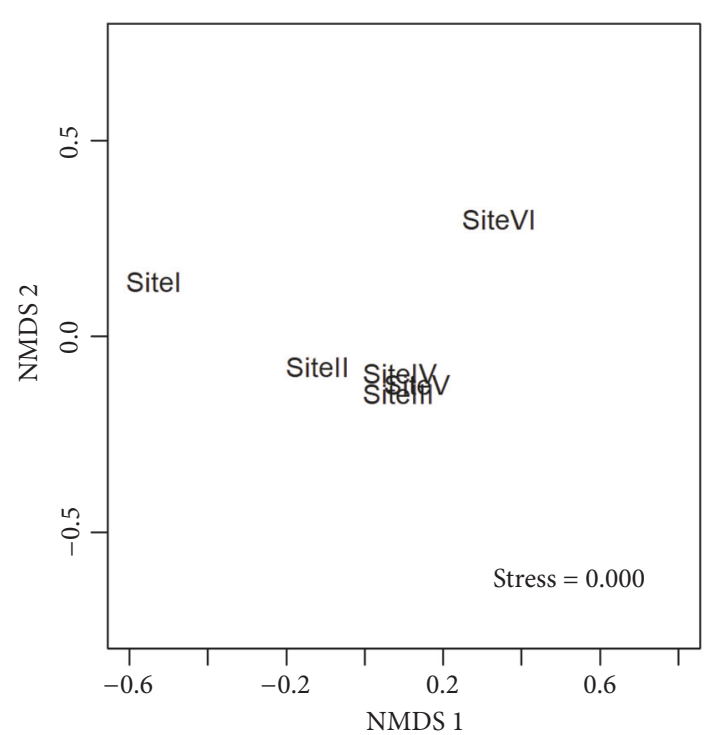

(b)

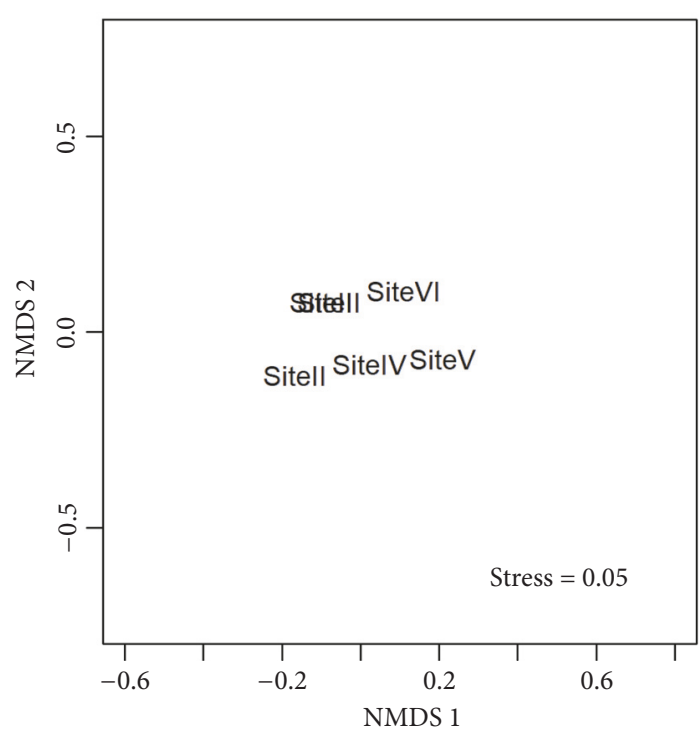

(d)

Figure 12: Nonmetric Multidimensional Scaling of the sites for (a) Janajagaran BZCF, (b) Musharni Mai BZCF, (c) Radha Krishna BZCF, and (d) Parsa Wildlife Reserve.

Species diversity (alpha diversity) was calculated by using Shannon-Wiener index [29] and it is defined as

$$
H=-\sum p i \log (b) p i
$$

where $p i$ is the proportional abundance of a species $i$ and $b$ is the base of the logarithm. The diversity function in the vegan package uses natural logarithms as the default while calculating Shannon-Wiener index, and 1- Simpson's alpha (which also describes overall alpha diversity) is calculated as 1 $-\Sigma \mathrm{pi}^{2}[30]$. All analyses for determining diversity (ShannonWiener, Simpson, and species accumulation curves) were performed using the diversity function in the vegan package [31].
To observe the functional association between forest community structure and distance from boundary lines of villages, a linear model was fit wherever applicable with the null hypothesis that there is no linear pattern between the structural attributes of forests and the distance from human settlements. Linear model assumptions were tested using the gvlma function in the gvlma package [32]. Residuals versus fitted and Q-Q plots were visualized.

Morisita's $\mathrm{I}_{\delta}$ index of dispersion was used for determining the spatial pattern of individuals of the predominant woody species. $\mathrm{I}_{\delta}$, which is independent of sample size and diversity [33], was computed as follows [34]: 

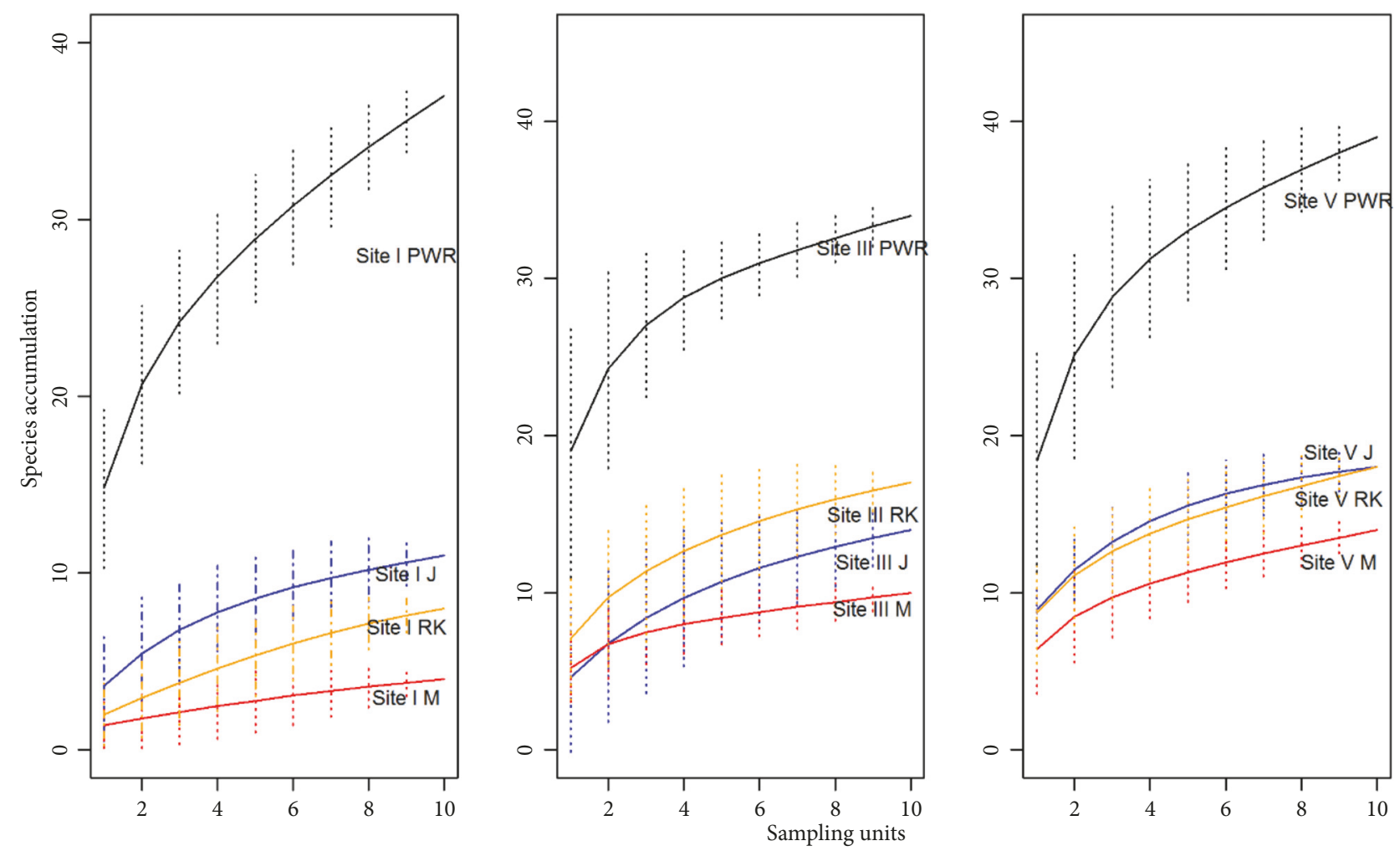

FIGURE 13: Species accumulation curves for different sites of studied forests plotted using Kindt's exact method. The curves are for Sites I, Sites III, and Sites V for Janajagaran (J), Musharni Mai (M), Radha Krishna (RK), and Parsa Wildlife Reserve (PWR) forests. The species accumulation curves reflected increase in number of species in the beginning with addition of sampling units. The vertical lines represent the standard deviations.

$$
I_{\delta}=q \frac{\sum x_{i}\left(x_{i}-1\right)}{N(N-1)}
$$

where $\mathrm{q}$ is the total number of subplots, $\mathrm{N}$ is the total number of individuals of the species in $\mathrm{q}$ subplots, and $\mathrm{x}$ is the number of individuals of a species in a subplot. Species were considered predominant if IVI $>10$ observed in any one of the sites of the forests. We used dispindmorisita function in the vegan package to calculate intraspecific aggregation [31].

To examine the dissimilarity and similarity in species composition between the sites in the forests, Bray-Curtis Index (BCI) was used. BCI is a rank-order index and values were used to determine a standardized species score to combine the measurements of IVI in the woody plant species. The values of $\mathrm{BCI}$ range from 0 to 1 . The value 1 reflects no similarity whereas 0 reflects complete similarity between plots. BCI of dissimilarity was calculated between the sites (from the edge to the interior of the forests) based on the IVI values determined for each species. Vegdist and hclust functions in the vegan package were used for determining dissimilarity and clustering (Ward.D2 group linkage), respectively [31]. Dissimilarity $\left(\right.$ DIS $_{\mathrm{jk}}$ ) between sites $\mathrm{j}$ and $\mathrm{k}$ using $\mathrm{BCI}$ can be expressed as follows [35]:

$$
D I S_{j k}=\frac{\sum_{i}^{p} a b s\left(y_{i j}-y_{i k}\right)}{\sum_{i}^{p}\left(y_{i j}+y_{i k}\right)}
$$

where $y_{i j}$ and $y_{i k}$ represent measures of species $i$ in the sample sites $\mathrm{j}$ and $\mathrm{k}$ and abs indicates absolute value. To compare the dissimilarity in the forest community between sites, a matrix representation of the DIS $\mathrm{j}_{\mathrm{k}}$ and the similarity $\left(\mathrm{S}_{\mathrm{jk}}=1-\mathrm{DIS}_{\mathrm{jk}}\right)$ between the paired sites were tabulated and compared. A multivariate agglomerative clustering using Ward.D2 group linkage based on the Bray-Curtis distance of IVI values was performed.

We also determined the associated plant community composition and similarity between sites based on IVI of the species using Nonmetric Multidimensional Scaling (NMDS) ordination to collapse information from multiple species into just a few, so that they can be visualized and interpreted. In community ecology, NMDS is commonly regarded as the most robust unconstrained ordination method [36] and considered as an indirect gradient analysis approach for producing an ordination based on a distance or dissimilarity matrix. We chose Bray-Curtis distance measure and a maximum of 200 iterations for NMDS distance matrix. The analysis was formed with the metaMDS function in the vegan package [31]. To minimize the stress (usually the stress values more than 0.2 should be interpreted with caution and more than 0.3 are highly suspicious), NMDS was projected in $\mathrm{K}=3$ dimensions (resulting in stress value for all our analysis less than 0.05; Shepard stress plots were visualized). All statistical analyses were performed in $\mathrm{R}$ [37]. 
TABLE 7: IVI of species in Janajagaran BZCF.

\begin{tabular}{|c|c|c|c|c|c|c|c|}
\hline Species code & Name of the species & Site I & Site II & Site III & Site IV & Site V & Site VI \\
\hline 1 & Shorea robusta Gaertn. & 190.93 & 216.11 & 188.25 & 146.09 & 112.11 & 75.00 \\
\hline 2 & $\begin{array}{c}\text { Adina cordifolia (Willd. ex } \\
\text { Roxb.) Benth. \& Hook. f. ex } \\
\text { Brandis }\end{array}$ & 32.81 & 4.62 & 8.21 & & 9.47 & \\
\hline 3 & $\begin{array}{c}\text { Lannea coromandelica } \\
\text { (Houtt.) Merr. }\end{array}$ & 14.96 & & 3.84 & 21.80 & 4.44 & 9.96 \\
\hline 4 & $\begin{array}{c}\text { Lagerstroemia parviflora } \\
\text { Roxb. } \\
\end{array}$ & 10.61 & 35.60 & 32.71 & 41.19 & 36.87 & 36.11 \\
\hline 5 & $\begin{array}{l}\text { Schleichera oleosa (Lour.) } \\
\text { Oken }\end{array}$ & 3.77 & & 2.33 & 2.58 & 1.70 & 7.76 \\
\hline 6 & $\begin{array}{c}\text { Terminalia bellirica } \\
\text { (Gaertn.) Roxb. }\end{array}$ & 5.18 & & & & & 3.07 \\
\hline 7 & Careya arborea Roxb. & 4.36 & & 3.20 & & 7.56 & 7.18 \\
\hline 8 & Casearia graveolens Dalzell & 13.19 & 7.39 & 10.40 & 13.16 & 25.42 & 28.89 \\
\hline 9 & Cassia fistula L. & 7.62 & 3.78 & 12.87 & 2.44 & 2.76 & 1.69 \\
\hline 10 & $\begin{array}{l}\text { Mallotus philippensis } \\
\text { (Lam.) Müll.-Arg. }\end{array}$ & 13.50 & 3.64 & 10.39 & 38.33 & 23.52 & 30.79 \\
\hline 11 & Aegle marmelos (L.) Correa & 3.07 & & 2.33 & & & \\
\hline 12 & Dillenia pentagyna Roxb. & & 5.24 & 6.31 & 22.48 & 24.16 & 28.92 \\
\hline 13 & Syzygium cumini (L.) Skeels & & 20.00 & 10.11 & & 5.90 & 5.50 \\
\hline 14 & $\begin{array}{c}\text { Dysoxylum gobara } \\
\text { (Buch.-Ham.) Merr. }\end{array}$ & & 3.61 & & & & \\
\hline 15 & Semecarpus anacardium L.f. & & & 4.79 & & 11.79 & 6.22 \\
\hline 16 & $\begin{array}{l}\text { Hymenodictyon excelsum } \\
\text { Wall. }\end{array}$ & & & 4.26 & & & \\
\hline 17 & Albizia sps. & & & & 3.64 & & \\
\hline 18 & $\begin{array}{c}\text { Miliusa velutina (Dunal) } \\
\text { Hook. f. \& Thoms. }\end{array}$ & & & & 2.44 & 6.95 & 27.50 \\
\hline 19 & Ehretia laevis Roxb. & & & & 3.42 & 2.00 & \\
\hline 20 & $\begin{array}{l}\text { Cleistocalyx operculatus } \\
\text { (Roxb.) Meer. \& Perry }\end{array}$ & & & & 2.45 & & \\
\hline 21 & $\begin{array}{c}\text { Terminalia alata Heyne ex } \\
\text { Roth }\end{array}$ & & & & & 17.03 & 15.13 \\
\hline 22 & Terminalia chebula Retz. & & & & & 2.60 & 1.74 \\
\hline 23 & Buchanania latifolia Roxb. & & & & & 1.30 & \\
\hline 24 & Sterculia villosa Roxb. & & & & & 4.41 & 1.70 \\
\hline 25 & Ficus religiosa $\mathrm{L}$. & & & & & & 2.41 \\
\hline 26 & $\begin{array}{c}\text { Anogeissus latifolius (Roxb. } \\
\text { ex DC.) Bedd. }\end{array}$ & & & & & & 6.03 \\
\hline 27 & Dalbergia latifolia Roxb. & & & & & & 2.15 \\
\hline 28 & $\begin{array}{l}\text { Wendlandia tinctoria } \\
\text { (Roxb.) DC. }\end{array}$ & & & & & & 2.26 \\
\hline
\end{tabular}

\section{Results}

3.1. Community Structure and Distribution of Woody Plants. The studied BZCFs and PWR are S. robusta dominated mixed forests. The forests exhibit high total densities of woody plants (saplings, poles, and trees) but also high variance within forest sites (Figure 2 ). Total density $( \pm$ SD) of woody species in Janajagaran BZCF ranged from $231 \pm 79$ stems $^{-1}$ to
$658 \pm 97$ stems ha ${ }^{-1}$ varying across different distances towards the forest interior from the boundary lines of the villages. Similarly, Musharni Mai BZCF and Radha Krishna BZCF also showed the wide range of variation in stem density ( \pm SD) from $286 \pm 45$ to $753 \pm 159$ stems $\mathrm{ha}^{-1}$ and $323 \pm 112$ stems ha ${ }^{-1}$ to $643 \pm 71.81$ stems ha $^{-1}$, respectively. In PWR, the range of variation of densities $( \pm$ SD) was from $607 \pm 113$ to $1021 \pm 311$ stems ha ${ }^{-1}$ (Appendix C, Tables 3-6). The median 
TABLE 8: IVI of species in Musharni Mai BZCF.

\begin{tabular}{|c|c|c|c|c|c|c|c|}
\hline Species code & Name of the species & Site I & Site II & Site III & Site IV & Site V & Site VI \\
\hline 1 & Shorea robusta Gaertn. & 268.26 & 183.83 & 151.92 & 159.47 & 148.73 & 116.36 \\
\hline 2 & $\begin{array}{c}\text { Adina cordifolia (Willd. ex } \\
\text { Roxb.) Benth. \& Hook. f. ex } \\
\text { Brandis }\end{array}$ & 9.08 & 3.72 & 4.49 & & 2.78 & 6.33 \\
\hline 9 & Cassia fistula L. & 7.29 & 9.59 & 2.16 & 1.93 & 6.93 & \\
\hline 8 & Casearia graveolens Dalzell & 15.36 & 22.60 & 29.91 & 30.03 & 34.10 & 20.51 \\
\hline 12 & Dillenia pentagyna Roxb. & & 22.19 & 25.87 & 15.06 & 15.47 & 17.52 \\
\hline 13 & Syzygium cumini (L.) Skeels & & 2.90 & 30.90 & 8.34 & & \\
\hline 20 & $\begin{array}{c}\text { Cleistocalyx operculatus } \\
\text { (Roxb.) Meer. \& Perry }\end{array}$ & & 9.80 & 3.10 & 2.04 & & \\
\hline 21 & $\begin{array}{l}\text { Terminalia alata Heyne ex } \\
\text { Roth }\end{array}$ & & 7.16 & & 9.47 & & 2.75 \\
\hline 4 & $\begin{array}{c}\text { Lagerstroemia parviflora } \\
\text { Roxb. }\end{array}$ & & 21.11 & 24.64 & 34.56 & 25.39 & 54.35 \\
\hline 17 & Albizia sps. & & 4.98 & & & & \\
\hline 3 & $\begin{array}{c}\text { Lannea coromandelica } \\
\text { (Houtt.) Merr. }\end{array}$ & & 7.34 & 12.16 & 11.88 & 18.46 & \\
\hline 10 & $\begin{array}{l}\text { Mallotus philippensis } \\
\text { (Lam.) Müll.-Arg. }\end{array}$ & & 4.79 & 14.85 & 19.66 & 23.20 & 48.78 \\
\hline 16 & $\begin{array}{l}\text { Hymenodictyon excelsum } \\
\text { Wall. } \\
\end{array}$ & & & & 3.32 & 2.22 & \\
\hline 14 & $\begin{array}{l}\text { Dysoxylum gobara } \\
\text { (Buch.-Ham.) Merr. }\end{array}$ & & & & 4.24 & & 2.70 \\
\hline 7 & Careya arborea Roxb. & & & & & 2.27 & \\
\hline 15 & Semecarpus anacardium L.f. & & & & & 2.06 & 2.10 \\
\hline 5 & $\begin{array}{c}\text { Schleichera oleosa (Lour.) } \\
\text { Oken }\end{array}$ & & & & & 6.64 & \\
\hline 29 & Ficus benghalensis Linn. & & & & & 2.88 & \\
\hline 18 & $\begin{array}{c}\text { Miliusa velutina (Dunal) } \\
\text { Hook. f. \& Thoms. }\end{array}$ & & & & & 8.88 & 2.46 \\
\hline 26 & $\begin{array}{l}\text { Anogeissus latifolius (Roxb. } \\
\text { ex DC.) Bedd. }\end{array}$ & & & & & & 18.75 \\
\hline 56 & $\begin{array}{c}\text { Pyrus pashia Buch.- Ham. } \\
\text { ex D.Don }\end{array}$ & & & & & & 4.47 \\
\hline 31 & UnidentifiedI & & & & & & 2.94 \\
\hline
\end{tabular}

stem density was more than 400 individuals ha ${ }^{-1}$ (arbitrary value) in each site of PWR, but oscillations were observed across the sites in BZCFs. The variance of frequency indicates the abundance difference of woody species, within a site; high values indicate that the abundance of species in the plot differs from each other, whereas low values indicate that all the species have a similar pattern of abundance (Appendix C, Tables 3-6).

Significant pattern $(p>0.05)$ was not observed between the total density of species and the distance from the boundary lines of the villages in all the BZCFs (Figure 3). When stem densities were separated into the density of the dominant species $S$. robusta and the density of other woody species, a significant increasing linear trend was obtained between the density of other species (except S. robusta) and the distance from the boundary lines of the settlement areas (Figure 3) (Janajagaran BZCF: p < 0.05, Musharni Mai BZCF: $\mathrm{p}<0.05$, and Radha Krishna BZCF: $<0.01$, but no significant difference was observed for PWR: $\mathrm{p}>0.05$ ). Similarly, the assemblage of $S$. robusta, when categorized as saplings, poles, and trees, reflected that the poles and trees had a high density near the human settlement areas in BZCFs (Figure 4). The BZCFs near the human settlements were receiving intense management and protection of the poles and tree-sized individuals of S. robusta. Densification has occurred in the area with very fewer plant species. The density of trees of S. robusta in the edges was very high above the estimated maximum density (85 stems ha ${ }^{-1}$ ) of fully grown mature trees of $S$. robusta which 1 ha forest area can support. For PWR such difference in the density of S. robusta along the edge to the interior was not observed (Figure 4). 
TABLE 9: IVI of species in Radha Krishna BZCF.

\begin{tabular}{|c|c|c|c|c|c|c|c|}
\hline Species code & Name of the species & Site I & Site II & Site III & Site IV & Site V & Site VI \\
\hline 1 & Shorea robusta Gaertn. & 228.32 & 176.61 & 137.14 & 130.12 & 104.46 & 57.57 \\
\hline 2 & $\begin{array}{c}\text { Adina cordifolia (Willd. ex } \\
\text { Roxb.) Benth. \& Hook. f. ex } \\
\text { Brandis }\end{array}$ & 7.39 & 10.17 & 14.76 & 8.87 & 4.61 & 10.04 \\
\hline 3 & $\begin{array}{c}\text { Lannea coromandelica } \\
\text { (Houtt.) Merr. }\end{array}$ & 13.31 & 3.03 & 13.96 & 13.69 & 8.03 & 5.93 \\
\hline 21 & $\begin{array}{l}\text { Terminalia alata Heyne ex } \\
\text { Roth }\end{array}$ & 19.56 & 7.36 & 16.06 & 9.72 & 10.51 & 19.41 \\
\hline 12 & Dillenia pentagyna Roxb. & 6.81 & 15.13 & 22.69 & 21.04 & 17.26 & 23.97 \\
\hline 6 & $\begin{array}{l}\text { Terminalia bellirica } \\
\text { (Gaertn.) Roxb. }\end{array}$ & 8.66 & 8.79 & 5.17 & 10.26 & 18.22 & 19.90 \\
\hline 4 & $\begin{array}{c}\text { Lagerstroemia parviflora } \\
\text { Roxb. }\end{array}$ & 10.63 & 35.82 & 27.53 & 27.49 & 27.99 & 17.11 \\
\hline 8 & Casearia graveolens Dalzell & 5.32 & 16.33 & 12.68 & 15.43 & 19.35 & 14.37 \\
\hline 32 & $\begin{array}{l}\text { Baisake (Local name: } \\
\text { Central Terai, Nepal) }\end{array}$ & & 2.38 & & & 1.31 & \\
\hline 7 & Careya arborea Roxb. & & 2.94 & 4.16 & 1.75 & 8.83 & 5.61 \\
\hline 5 & $\begin{array}{c}\text { Schleichera oleosa (Lour.) } \\
\text { Oken }\end{array}$ & & 2.55 & 4.13 & 5.92 & 6.10 & 3.18 \\
\hline 10 & $\begin{array}{l}\text { Mallotus philippensis } \\
\text { (Lam.) Müll.-Arg. }\end{array}$ & & 14.45 & 26.63 & 29.17 & 49.90 & 84.95 \\
\hline 33 & $\begin{array}{c}\text { Sapium insigne (Royle) } \\
\text { Benth. ex Hook. f. }\end{array}$ & & 2.22 & & & & \\
\hline 9 & Cassia fistula L. & & 2.22 & 1.61 & & 1.31 & \\
\hline 18 & $\begin{array}{c}\text { Miliusa velutina (Dunal) } \\
\text { Hook. f. \& Thoms. }\end{array}$ & & & 2.01 & 8.46 & 15.56 & 1.98 \\
\hline 15 & $\begin{array}{c}\text { Semecarpus anacardium L. } \\
\text { f. }\end{array}$ & & & 5.27 & 11.14 & & 1.47 \\
\hline 26 & $\begin{array}{c}\text { Anogeissus latifolius (Roxb. } \\
\text { ex DC.) Bedd. }\end{array}$ & & & 2.30 & & & \\
\hline 13 & Syzygium cumini (L.) Skeels & & & 2.29 & & & 1.64 \\
\hline 34 & Lagerstroemia reginae Roxb. & & & 1.61 & & & 1.75 \\
\hline 19 & Ehretia laevis Roxb. & & & & 1.91 & & 1.84 \\
\hline 25 & Ficus religiosa $\mathrm{L}$. & & & & 3.51 & & 1.89 \\
\hline 35 & $\begin{array}{l}\text { Madhuca longifolia } \\
\text { (Koeing) Macbride }\end{array}$ & & & & 1.52 & & \\
\hline 36 & $\begin{array}{l}\text { Duabanga grandiflora } \\
\text { (Roxb. ex DC.) Walp. }\end{array}$ & & & & & 2.62 & \\
\hline 37 & Grewia eriocarpa Juss. & & & & & 1.31 & \\
\hline 38 & $\begin{array}{c}\text { Litsea monopetala (Roxb.) } \\
\text { Pers. }\end{array}$ & & & & & 1.31 & 5.63 \\
\hline 39 & Unidentified II & & & & & 1.31 & \\
\hline 40 & Bombax ceiba L. & & & & & & 6.34 \\
\hline 17 & Albizia sps. & & & & & & 3.57 \\
\hline 14 & $\begin{array}{l}\text { Dysoxylum gobara } \\
\text { (Buch.-Ham.) Merr. }\end{array}$ & & & & & & 1.64 \\
\hline 41 & Toona ciliata M. Roem. & & & & & & 3.67 \\
\hline 42 & Trewia nudiflora Linn. & & & & & & 1.56 \\
\hline 43 & Premna barbata Wall. & & & & & & 2.05 \\
\hline 27 & Dalbergia latifolia Roxb. & & & & & & 1.47 \\
\hline 44 & Croton $\mathrm{sp}$. & & & & & & 1.46 \\
\hline
\end{tabular}


TABle 10: IVI of species in Parsa Wildlife Reserve.

\begin{tabular}{|c|c|c|c|c|c|c|c|}
\hline Species code & Name of the species & Site I & Site II & Site III & Site IV & Site V & Site VI \\
\hline 8 & Casearia graveolens Dalzell & 16.20 & 18.69 & 12.30 & 15.48 & 4.96 & 4.95 \\
\hline 4 & $\begin{array}{c}\text { Lagerstroemia parviflora } \\
\text { Roxb. }\end{array}$ & 28.03 & 35.81 & 23.25 & 18.65 & 21.96 & 15.84 \\
\hline 45 & Bridelia retusa (L.) Spreng. & 0.85 & 3.15 & 6.74 & 4.04 & 1.81 & 3.51 \\
\hline 18 & $\begin{array}{c}\text { Miliusa velutina (Dunal) } \\
\text { Hook. f. \& Thoms. }\end{array}$ & 12.59 & 21.44 & 14.03 & 13.12 & 24.42 & 17.11 \\
\hline 46 & Phyllanthus emblica Linn. & 6.00 & 1.19 & 4.30 & 13.76 & 5.99 & 6.46 \\
\hline 15 & Semecarpus anacardium L.f. & 0.91 & & & & 0.74 & 0.69 \\
\hline 22 & Terminalia chebula Retz. & 8.02 & 6.92 & 6.03 & 0.99 & 0.82 & \\
\hline 7 & Careya arborea Roxb. & 3.63 & 2.15 & 3.26 & 1.58 & 5.89 & 0.66 \\
\hline 1 & Shorea robusta Gaertn. & 101.09 & 72.09 & 90.43 & 74.39 & 72.41 & 95.39 \\
\hline 27 & Dalbergia latifolia Roxb. & 7.96 & 9.03 & 10.84 & 6.87 & 5.94 & 6.92 \\
\hline 12 & Dillenia pentagyna Roxb. & 13.24 & 19.78 & 15.85 & 12.75 & 6.58 & 4.57 \\
\hline 21 & $\begin{array}{l}\text { Terminalia alata Heyne ex } \\
\text { Roth }\end{array}$ & 13.69 & 15.55 & 11.17 & 10.55 & 12.71 & 13.78 \\
\hline 2 & $\begin{array}{c}\text { Adina cordifolia (Willd. ex } \\
\text { Roxb.) Benth. \& Hook. f. ex } \\
\text { Brandis }\end{array}$ & 10.12 & 1.66 & 5.00 & 8.17 & 9.97 & 13.95 \\
\hline 13 & Syzygium cumini (L.) Skeels & 5.67 & 12.24 & 7.78 & 0.99 & 0.81 & 2.51 \\
\hline 47 & $\begin{array}{c}\text { Desmodium oojenense } \\
\text { (Roxb.) Ohashi }\end{array}$ & 15.74 & 12.51 & 5.83 & 24.32 & 13.45 & 13.93 \\
\hline 26 & $\begin{array}{l}\text { Anogeissus latifolius (Roxb. } \\
\text { ex DC.) Bedd. }\end{array}$ & 8.07 & 7.92 & 4.87 & 13.34 & 4.44 & 10.80 \\
\hline 48 & Garuga pinnata Roxb. & 6.97 & 8.47 & 15.50 & 7.70 & 11.72 & 13.53 \\
\hline 3 & $\begin{array}{c}\text { Lannea coromandelica } \\
\text { (Houtt.) Merr. }\end{array}$ & 0.83 & 2.63 & 3.19 & 3.51 & 0.86 & 11.21 \\
\hline 23 & Buchanania latifolia Roxb. & 10.68 & 9.14 & 12.54 & 11.12 & & 0.67 \\
\hline 19 & Ehretia laevis Roxb. & 0.83 & & & 5.32 & 3.01 & 3.82 \\
\hline 54 & $\begin{array}{c}\text { Lyonia ovalifolia (Wall.) } \\
\text { Drude } \\
\end{array}$ & 5.65 & 3.72 & 8.81 & 3.16 & 4.34 & 5.01 \\
\hline 49 & $\begin{array}{c}\text { Stereospermum personatum } \\
\text { ( Hassk.) Chatterjee }\end{array}$ & 2.83 & 3.92 & 3.30 & 7.07 & 2.84 & 0.67 \\
\hline 10 & $\begin{array}{l}\text { Mallotus philippensis } \\
\text { (Lam.) Müll.-Arg. }\end{array}$ & 0.84 & & & & 7.90 & 1.31 \\
\hline 33 & $\begin{array}{c}\text { Sapium insigne (Royle) } \\
\text { Benth. ex Hook. f. }\end{array}$ & 1.69 & 3.44 & 4.60 & 3.40 & 6.36 & 2.05 \\
\hline 50 & Bauhinia malabarica Roxb. & 0.83 & & & 0.69 & & 3.21 \\
\hline 51 & Bauhinia purpurea L. & 3.71 & 5.88 & 4.28 & 1.38 & 3.24 & 5.75 \\
\hline 20 & $\begin{array}{l}\text { Cleistocalyx operculatus } \\
\text { (Roxb.) Meer. \& Perry }\end{array}$ & 1.77 & 2.25 & & & & \\
\hline 17 & Albizia sps. & 0.96 & & 3.04 & 4.67 & 3.77 & 2.52 \\
\hline 52 & $\begin{array}{c}\text { Putalikath (Local name: } \\
\text { Central Terai, Nepal) }\end{array}$ & 1.82 & 5.84 & 0.66 & 0.76 & & 1.36 \\
\hline 14 & $\begin{array}{l}\text { Dysoxylum gobara } \\
\text { (Buch.-Ham.) Merr. }\end{array}$ & 1.95 & 1.62 & & & 22.96 & 4.36 \\
\hline 5 & $\begin{array}{l}\text { Schleichera oleosa (Lour.) } \\
\text { Oken } \\
\end{array}$ & 0.86 & & & 2.84 & 5.28 & 3.10 \\
\hline 6 & $\begin{array}{c}\text { Terminalia bellirica } \\
\text { (Gaertn.) Roxb. }\end{array}$ & 0.98 & 2.20 & 2.99 & 3.66 & 6.12 & 1.32 \\
\hline 55 & Tamarindus indica L. & & 0.69 & & & & \\
\hline
\end{tabular}


TABLE 10: Continued.

\begin{tabular}{|c|c|c|c|c|c|c|c|}
\hline Species code & Name of the species & Site I & Site II & Site III & Site IV & Site V & Site VI \\
\hline 56 & $\begin{array}{l}\text { Pyrus pashia Buch.- Ham. } \\
\text { ex D.Don }\end{array}$ & & 0.71 & & & & \\
\hline 37 & Grewia eriocarpa Juss. & 1.70 & 4.94 & 5.94 & 6.93 & 6.99 & 6.44 \\
\hline 16 & $\begin{array}{l}\text { Hymenodictyon excelsum } \\
\text { Wall. }\end{array}$ & 0.83 & 0.71 & 1.27 & 4.18 & 0.77 & 5.90 \\
\hline 57 & Bauhinia variegata $\mathrm{L}$. & & 1.45 & 0.63 & & & \\
\hline 58 & Ficus racemosa L. & & 0.69 & & & 0.73 & \\
\hline 9 & Cassia fistula L. & 0.82 & 0.68 & 0.75 & & & \\
\hline 53 & $\begin{array}{c}\text { Bauhinia vahlii Wight \& } \\
\text { Arn } \\
\end{array}$ & 0.83 & 0.89 & & 4.36 & & 0.67 \\
\hline 59 & $\begin{array}{l}\text { Spatholobus parviflorus } \\
\text { (Roxb.) Kuntze }\end{array}$ & & & 0.95 & & & \\
\hline 60 & $\begin{array}{l}\text { Nyctanthes arbor-tristis } \\
\text { Linn. }\end{array}$ & & & 7.78 & & & \\
\hline 61 & Viscum album Linn. & & & 0.66 & 1.71 & 3.15 & 6.26 \\
\hline 62 & Gmelina arborea Roxb. & & & 0.79 & 4.60 & 2.40 & 1.77 \\
\hline 63 & Antidesma acidum Retz. & & & 0.64 & & 1.43 & 2.13 \\
\hline 64 & $\begin{array}{c}\text { Xeromphis spinosa (Thunb) } \\
\text { Keay }\end{array}$ & & & & 0.69 & & 1.99 \\
\hline 28 & $\begin{array}{c}\text { Wendlandia tinctoria } \\
\text { (Roxb.) DC. }\end{array}$ & & & & 1.74 & 0.73 & 2.25 \\
\hline 65 & $\begin{array}{c}\text { Millettia extensa (Benth.) } \\
\text { Baker } \\
\end{array}$ & & & & 0.81 & & \\
\hline 66 & Melia azedarach Linn. & & & & 0.73 & & \\
\hline 67 & $\begin{array}{c}\text { Holarrhena pubescens } \\
\text { (Buch.-Ham.) Wall. ex G. } \\
\text { Don }\end{array}$ & & & & & 1.15 & 1.66 \\
\hline 40 & Bombax ceiba $\mathrm{L}$ & & & & & 9.79 & \\
\hline 68 & Alstonia scholaris (L.) R. Br. & & & & & 0.79 & \\
\hline 69 & $\begin{array}{c}\text { Cornus oblonga (Wall.) } \\
\text { Sojak }\end{array}$ & & & & & 0.74 & \\
\hline 34 & Lagerstroemia reginae Roxb. & 0.82 & & & & & \\
\hline
\end{tabular}

We found a total of 69 woody species belonging to 30 families in all the sample plots of the studied forests. Plant species belonging to the Fabaceae family were the most abundant (12) followed by those belonging to the families Euphorbiaceae (7), Combretaceae (4), and Rubiaceae (4). The number of species varied within the sites from the forest edges to the interior. The numbers of woody species increased significantly as a function of the distance from the village boundaries for Janajagaran $(\mathrm{p}<0.05)$ and Radha Krishna $(\mathrm{p}<0.05)$ BZCFs. In the case of Musharni Mai BZCF, the number of species observed was the least for the site near the edge but a nonsignificant pattern was observed $(p>0.05)$. For the control forest, such a trend was not observed $(\mathrm{p}>0.05)$ (Figure 5). In BZCFs, species like Dalbergia sissoo, Dalbergia latifolia, Wendlandia tinctoria, Bombax ceiba, Toona ciliata, Trewia nudiflora, and Premma barabata were recorded only in the innermost sites.

The cross-sectional area (basal area) per unit sampling area is an indicator of woody species dominance. Basal area correlates with maturity and age of the woody plant species. Our study showed mixed patterns between total dominance and distance from the boundary lines of villages (Figure 6). A decreased linear trend was observed in Janajagaran BZCF ( $p$ $<0.05$ ), a linear trend was absent in Musharni Mai BZCF, and an increased trend was observed in Radha Krishna BZCF ( $p$ $<0.001)$. Though no linear trend was present in the Musharni Mai BZCF, a decrease in the basal area moving from the edge to the interior of the forest was observed. As expected, PWR showed the oscillating pattern of increase and decrease of the total basal area along the sites. An interesting result was observed when the total basal area was segregated as contributed by $S$. robusta and the basal area of other species except for S. robusta. In BZCFs edges, the majority of the basal area was contributed by $S$. robusta but its value was observed decreasing when moving across the interior of the forests. In contrast, the basal area of other species showed an increasing trend $(\mathrm{p}<0.05)$ in BZCFs (Figures 6 and 7) except for the control forest. Based on $\%$ basal area, the forest near 
TABLE 11: IVI of predominant species and Morisita Index of Dispersion in Janajagaran BZCF.

\begin{tabular}{|c|c|c|c|c|c|c|c|}
\hline $\begin{array}{l}\text { Species } \\
\text { code }\end{array}$ & Name of the species & Site I & Site II & Site III & Site IV & Site V & Site VI \\
\hline 1 & Shorea robusta Gaertn. & $\begin{array}{c}190.93 \\
(1.2) \\
\end{array}$ & $\begin{array}{c}216.11 \\
(1.1) \\
\end{array}$ & $\begin{array}{c}188.25 \\
(1.1) \\
\end{array}$ & $\begin{array}{c}146.09 \\
(1.2) \\
\end{array}$ & $\begin{array}{c}112.11 \\
(1.2)\end{array}$ & $\begin{array}{c}75.00 \\
(1.5)\end{array}$ \\
\hline 2 & $\begin{array}{c}\text { Adina cordifolia (Willd. ex } \\
\text { Roxb.) Benth. \& Hook. f. ex } \\
\text { Brandis }\end{array}$ & $\begin{array}{c}32.81 \\
(10)\end{array}$ & $\begin{array}{l}4.62 \\
(10)\end{array}$ & $\begin{array}{c}8.21 \\
(4.7)\end{array}$ & & $\begin{array}{l}9.47 \\
(2.3)\end{array}$ & \\
\hline 3 & $\begin{array}{c}\text { Lannea coromandelica } \\
\text { (Houtt.) Merr. }\end{array}$ & $\begin{array}{c}14.96 \\
(3.1) \\
\end{array}$ & & $\begin{array}{l}3.84 \\
(10) \\
\end{array}$ & $\begin{array}{l}21.80 \\
(3.8) \\
\end{array}$ & $\begin{array}{l}4.44 \\
(4.7) \\
\end{array}$ & $\begin{array}{l}9.96 \\
(3.1) \\
\end{array}$ \\
\hline 4 & $\begin{array}{c}\text { Lagerstroemia parviflora } \\
\text { Roxb. } \\
\end{array}$ & $\begin{array}{l}10.61 \\
(3.8) \\
\end{array}$ & $\begin{array}{c}35.60 \\
(1.6) \\
\end{array}$ & $\begin{array}{l}32.71 \\
(1.4) \\
\end{array}$ & $\begin{array}{l}41.19 \\
(1.3) \\
\end{array}$ & $\begin{array}{c}36.87 \\
(1.2) \\
\end{array}$ & $\begin{array}{l}36.11 \\
(1.4) \\
\end{array}$ \\
\hline 8 & Casearia graveolens Dalzell & $\begin{array}{l}13.19 \\
(2.5) \\
\end{array}$ & $\begin{array}{r}7.39 \\
(5.4) \\
\end{array}$ & $\begin{array}{c}10.40 \\
(2.9) \\
\end{array}$ & $\begin{array}{l}13.16 \\
(2.7) \\
\end{array}$ & $\begin{array}{c}25.42 \\
(1.2) \\
\end{array}$ & $\begin{array}{c}28.89 \\
(1.9) \\
\end{array}$ \\
\hline 9 & Cassia fistula L. & $\begin{array}{c}7.62 \\
(5.0) \\
\end{array}$ & $\begin{array}{l}3.78 \\
(10) \\
\end{array}$ & $\begin{array}{l}12.87 \\
(2.5)\end{array}$ & $\begin{array}{c}2.44 \\
(10)\end{array}$ & $\begin{array}{l}2.76 \\
(5.4)\end{array}$ & $\begin{array}{l}1.69 \\
(10)\end{array}$ \\
\hline 10 & $\begin{array}{l}\text { Mallotus philippensis } \\
\text { (Lam.) Müll.-Arg. }\end{array}$ & $\begin{array}{l}13.50 \\
(3.4) \\
\end{array}$ & $\begin{array}{l}3.64 \\
(10) \\
\end{array}$ & $\begin{array}{l}10.39 \\
(3.7) \\
\end{array}$ & $\begin{array}{c}38.33 \\
(1.4) \\
\end{array}$ & $\begin{array}{c}23.52 \\
(1.6) \\
\end{array}$ & $\begin{array}{c}30.79 \\
(1.2) \\
\end{array}$ \\
\hline 12 & Dillenia pentagyna Roxb. & & $\begin{array}{l}5.24 \\
(10) \\
\end{array}$ & $\begin{array}{r}6.31 \\
(6.7) \\
\end{array}$ & $\begin{array}{c}22.48 \\
(1.6) \\
\end{array}$ & $\begin{array}{c}24.16 \\
(1.2) \\
\end{array}$ & $\begin{array}{c}28.92 \\
(1.6) \\
\end{array}$ \\
\hline 13 & Syzygium cumini (L.) Skeels & & $\begin{array}{c}20.00 \\
(2.3)\end{array}$ & $\begin{array}{l}10.11 \\
(3.1) \\
\end{array}$ & & $\begin{array}{l}5.90 \\
(4.3) \\
\end{array}$ & $\begin{array}{l}5.50 \\
(4.7) \\
\end{array}$ \\
\hline 15 & Semecarpus anacardium L.f. & & & $\begin{array}{l}4.79 \\
(4.7) \\
\end{array}$ & & $\begin{array}{l}11.79 \\
(1.7) \\
\end{array}$ & $\begin{array}{l}6.22 \\
(5.4) \\
\end{array}$ \\
\hline 18 & $\begin{array}{l}\text { Miliusa velutina (Dunal) } \\
\text { Hook. f. \& Thoms. }\end{array}$ & & & & $\begin{array}{l}2.44 \\
(10)\end{array}$ & $\begin{array}{l}6.95 \\
(3.6)\end{array}$ & $\begin{array}{c}27.50 \\
(1.7)\end{array}$ \\
\hline 21 & $\begin{array}{l}\text { Terminalia alata Heyne ex } \\
\text { Roth }\end{array}$ & & & & & $\begin{array}{l}17.03 \\
(1.2)\end{array}$ & $\begin{array}{l}15.13 \\
(1.5)\end{array}$ \\
\hline
\end{tabular}

TABLE 12: IVI of predominant species and Morisita Index of Dispersion in Musharni Mai BZCF.

\begin{tabular}{|c|c|c|c|c|c|c|c|}
\hline $\begin{array}{l}\text { Species } \\
\text { code }\end{array}$ & Name of the species & Site I & Site II & Site III & Site IV & Site V & Site VI \\
\hline 1 & Shorea robusta Gaertn. & $\begin{array}{c}268.26 \\
(1.03)\end{array}$ & $\begin{array}{l}183.83 \\
(1.04)\end{array}$ & $\begin{array}{c}151.92 \\
(1.2)\end{array}$ & $\begin{array}{c}159.47 \\
(1.2)\end{array}$ & $\begin{array}{l}148.73 \\
(1.04)\end{array}$ & $\begin{array}{c}116.36 \\
(1.3)\end{array}$ \\
\hline 8 & Casearia graveolens Dalzell & $\begin{array}{c}15.36 \\
(7.5) \\
\end{array}$ & $\begin{array}{c}22.60 \\
(1.3) \\
\end{array}$ & $\begin{array}{c}29.91 \\
(1.3) \\
\end{array}$ & $\begin{array}{c}30.03 \\
(1.3) \\
\end{array}$ & $\begin{array}{c}34.10 \\
(1.2) \\
\end{array}$ & $\begin{array}{c}20.51 \\
(1.9) \\
\end{array}$ \\
\hline 12 & Dillenia pentagyna Roxb. & & $\begin{array}{c}22.19 \\
(1.8) \\
\end{array}$ & $\begin{array}{c}25.87 \\
(1.8) \\
\end{array}$ & $\begin{array}{c}15.06 \\
(2.1) \\
\end{array}$ & $\begin{array}{r}15.47 \\
(1.8) \\
\end{array}$ & $\begin{array}{l}17.52 \\
(1.7) \\
\end{array}$ \\
\hline 13 & Syzygium cumini (L.) Skeels & & $\begin{array}{l}2.90 \\
(10) \\
\end{array}$ & $\begin{array}{c}30.90 \\
(1.6)\end{array}$ & $\begin{array}{l}8.34 \\
(3.1)\end{array}$ & & \\
\hline 20 & $\begin{array}{l}\text { Cleistocalyx operculatus } \\
\text { (Roxb.) Meer. \& Perry }\end{array}$ & & $\begin{array}{l}9.80 \\
(3.1) \\
\end{array}$ & $\begin{array}{c}3.10 \\
(10.0) \\
\end{array}$ & $\begin{array}{c}2.04 \\
(10.0) \\
\end{array}$ & & \\
\hline 21 & $\begin{array}{l}\text { Terminalia alata Heyne ex } \\
\text { Roth }\end{array}$ & & $\begin{array}{c}7.16 \\
(4.7) \\
\end{array}$ & & $\begin{array}{l}9.47 \\
(3.1)\end{array}$ & & $\begin{array}{c}2.75 \\
(10.0)\end{array}$ \\
\hline 4 & $\begin{array}{c}\text { Lagerstroemia parviflora } \\
\text { Roxb. }\end{array}$ & & $\begin{array}{l}21.11 \\
(2.2)\end{array}$ & $\begin{array}{c}24.64 \\
(2.4)\end{array}$ & $\begin{array}{c}34.56 \\
(1.3)\end{array}$ & $\begin{array}{c}25.39 \\
(1.7)\end{array}$ & $\begin{array}{c}54.35 \\
(1.3)\end{array}$ \\
\hline 3 & $\begin{array}{c}\text { Lannea coromandelica } \\
\text { (Houtt.) Merr. }\end{array}$ & & $\begin{array}{l}7.34 \\
(4.7) \\
\end{array}$ & $\begin{array}{l}12.16 \\
(5.4) \\
\end{array}$ & $\begin{array}{c}11.88 \\
(3.1) \\
\end{array}$ & $\begin{array}{c}18.46 \\
(1.3) \\
\end{array}$ & \\
\hline 10 & $\begin{array}{l}\text { Mallotus philippensis } \\
\text { (Lam.) Müll.-Arg. }\end{array}$ & & $\begin{array}{l}4.79 \\
(5.4)\end{array}$ & $\begin{array}{l}14.85 \\
(2.2)\end{array}$ & $\begin{array}{c}19.66 \\
(1.8)\end{array}$ & $\begin{array}{c}23.20 \\
(2.3)\end{array}$ & $\begin{array}{c}48.78 \\
(1.1)\end{array}$ \\
\hline 26 & $\begin{array}{l}\text { Anogeissus latifolius (Roxb. } \\
\text { ex DC.) Bedd. }\end{array}$ & & & & & & $\begin{array}{c}18.75 \\
(1.7)\end{array}$ \\
\hline
\end{tabular}


TABLE 13: IVI of predominant species and Morisita Index of Dispersion in Radha Krishna BZCF.

\begin{tabular}{|c|c|c|c|c|c|c|c|}
\hline $\begin{array}{l}\text { Species } \\
\text { code }\end{array}$ & Name of the species & Site I & Site II & Site III & Site IV & Site V & Site VI \\
\hline 1 & Shorea robusta Gaertn. & $\begin{array}{c}228.32 \\
(1.1) \\
\end{array}$ & $\begin{array}{l}176.61 \\
(1.02) \\
\end{array}$ & $\begin{array}{c}137.14 \\
(1.1)\end{array}$ & $\begin{array}{c}130.12 \\
(1.1)\end{array}$ & $\begin{array}{c}104.46 \\
(1.1)\end{array}$ & $\begin{array}{c}57.57 \\
(1.1) \\
\end{array}$ \\
\hline 2 & $\begin{array}{c}\text { Adina cordifolia (Willd. ex } \\
\text { Roxb.) Benth. \& Hook. f. ex } \\
\text { Brandis }\end{array}$ & $\begin{array}{c}7.39 \\
(10.0)\end{array}$ & $\begin{array}{l}10.17 \\
(3.1)\end{array}$ & $\begin{array}{l}14.76 \\
(2.7)\end{array}$ & $\begin{array}{l}8.87 \\
(3.1)\end{array}$ & $\begin{array}{c}4.61 \\
(10.0)\end{array}$ & $\begin{array}{l}10.04 \\
(4.3)\end{array}$ \\
\hline 3 & $\begin{array}{c}\text { Lannea coromandelica } \\
\text { (Houtt.) Merr. }\end{array}$ & $\begin{array}{l}13.31 \\
(4.7)\end{array}$ & $\begin{array}{c}3.03 \\
(10.0)\end{array}$ & $\begin{array}{c}13.96 \\
(2.1)\end{array}$ & $\begin{array}{l}13.69 \\
(2.0)\end{array}$ & $\begin{array}{l}8.03 \\
(2.3)\end{array}$ & $\begin{array}{l}5.93 \\
(3.6)\end{array}$ \\
\hline 21 & $\begin{array}{c}\text { Terminalia alata Heyne ex } \\
\text { Roth }\end{array}$ & $\begin{array}{l}19.56 \\
(4.7) \\
\end{array}$ & $\begin{array}{l}7.36 \\
(4.7) \\
\end{array}$ & $\begin{array}{c}16.06 \\
(3.0) \\
\end{array}$ & $\begin{array}{l}9.72 \\
(3.6) \\
\end{array}$ & $\begin{array}{l}10.51 \\
(2.7) \\
\end{array}$ & $\begin{array}{l}19.41 \\
(1.7) \\
\end{array}$ \\
\hline 12 & Dillenia pentagyna Roxb. & $\begin{array}{c}6.81 \\
(10.0) \\
\end{array}$ & $\begin{array}{l}15.13 \\
(2.7) \\
\end{array}$ & $\begin{array}{c}22.69 \\
(1.5) \\
\end{array}$ & $\begin{array}{c}21.04 \\
(1.6) \\
\end{array}$ & $\begin{array}{l}17.26 \\
(1.2) \\
\end{array}$ & $\begin{array}{c}23.97 \\
(1.4) \\
\end{array}$ \\
\hline 6 & $\begin{array}{c}\text { Terminalia bellirica } \\
\text { (Gaertn.) Roxb. }\end{array}$ & $\begin{array}{c}8.66 \\
(10.0) \\
\end{array}$ & $\begin{array}{l}8.79 \\
(3.1) \\
\end{array}$ & $\begin{array}{l}5.17 \\
(4.7) \\
\end{array}$ & $\begin{array}{l}10.26 \\
(2.3) \\
\end{array}$ & $\begin{array}{c}18.22 \\
(1.9) \\
\end{array}$ & $\begin{array}{l}19.90 \\
(2.8) \\
\end{array}$ \\
\hline 4 & $\begin{array}{c}\text { Lagerstroemia parviflora } \\
\text { Roxb. }\end{array}$ & $\begin{array}{l}10.63 \\
(4.7)\end{array}$ & $\begin{array}{c}35.82 \\
(1.8)\end{array}$ & $\begin{array}{l}27.53 \\
(1.4)\end{array}$ & $\begin{array}{c}27.49 \\
(1.3)\end{array}$ & $\begin{array}{c}27.99 \\
(1.2)\end{array}$ & $\begin{array}{l}17.11 \\
(1.5)\end{array}$ \\
\hline 8 & Casearia graveolens Dalzell & $\begin{array}{c}5.32 \\
(10.0) \\
\end{array}$ & $\begin{array}{l}16.33 \\
(2.2) \\
\end{array}$ & $\begin{array}{c}12.68 \\
(1.8) \\
\end{array}$ & $\begin{array}{c}15.43 \\
(1.8) \\
\end{array}$ & $\begin{array}{l}19.35 \\
(1.4) \\
\end{array}$ & $\begin{array}{r}14.37 \\
(1.7) \\
\end{array}$ \\
\hline 10 & $\begin{array}{l}\text { Mallotus philippensis } \\
\text { (Lam.) Müll.-Arg. }\end{array}$ & & $\begin{array}{c}14.45 \\
(1.8) \\
\end{array}$ & $\begin{array}{c}26.63 \\
(1.5) \\
\end{array}$ & $\begin{array}{l}29.17 \\
(1.2) \\
\end{array}$ & $\begin{array}{c}49.90 \\
(1.2) \\
\end{array}$ & $\begin{array}{c}84.95 \\
(1.2) \\
\end{array}$ \\
\hline 18 & $\begin{array}{c}\text { Miliusa velutina (Dunal) } \\
\text { Hook. f. \& Thoms. }\end{array}$ & & & $\begin{array}{c}2.01 \\
(10.0)\end{array}$ & $\begin{array}{l}8.46 \\
(2.1) \\
\end{array}$ & $\begin{array}{l}15.56 \\
(2.8) \\
\end{array}$ & $\begin{array}{c}1.98 \\
(10.0) \\
\end{array}$ \\
\hline 15 & Semecarpus anacardium L.f. & & & $\begin{array}{l}5.27 \\
(3.6) \\
\end{array}$ & $\begin{array}{l}11.14 \\
(1.8) \\
\end{array}$ & & $\begin{array}{c}1.47 \\
(10.0) \\
\end{array}$ \\
\hline
\end{tabular}

the settlement areas was observed to have undergone biotic homogenization (S. robusta Terai Mixed Hardwood Forest to $S$. robusta Forest) due to disturbance and management interactions.

We calculated the Importance Value Index (IVI) for each species in every 1 ha plot. Though the forest was dominated by $S$. robusta, other species were identified as predominant species based on high IVI values (IVI > 10). Janajagaran BZCF, Musharni Mai BZCF, Radha Krishna BZCF, and Parsa Wildlife Reserve were observed to have 12, 9, 12, and 17 predominant species, respectively (Appendix D, Tables 7-10). In all the BZCFs, our results indicated that IVI of S. robusta was linearly decreasing (significant; $\mathrm{p}<0.05$ in all BZCFs) with moving farther from the villages, and consequently other species showed increasing IVI values with the distance. But the control forest did not show such an increasing or decreasing trend (Figure 8). The high IVI of S. robusta near the human settlement areas were due to the protection of $S$. robusta and thus increasing all the three parameters affecting IVI. Based on the variation of Morisita's dispersion index $\left(\mathrm{I}_{\delta}\right)$, all these predominant species exhibited clumped distribution (Appendix E, Tables 11-14). No effect on the distribution pattern of species according to the distance from the settlements was observed (all species exhibited $\mathrm{I}_{\delta}>$ 1). The clumped distribution of the species reflects that the distance between neighboring individuals is minimized for each species.

3.2. Species Diversity along the Distance from the Human Settlements. To examine the variations in the species diversity of woody plants, Shannon-Wiener index $\left(\mathrm{H}^{\prime}\right)$ and Simpson's index $(\lambda)$ were calculated for each plot and plotted against the distance from the village boundaries. The ShannonWiener index for the species diversity increased significantly $(p<0.05)$ for all the BZCFs (Figures 9(a), 9(b), and 9(c), respectively, for Janajagaran BZCF, Musharni Mai BZCF, and Radha Krishna BZCF) towards the forest edge to the interior. For PWR, this pattern was not observed (Figure 9(d)). At the nearer distance to the human settlements in BZCFs, all the sites showed very low diversity indicating a high dominance of $S$. robusta (the species receiving high management and restoration priority). For PWR, the index values were comparatively higher. Simpson's index of diversity, which ranges from 0 (highest diversity) to 1 (no diversity), also showed the similar pattern of increase when moving farther from the village boundary lines (Figure 10, 1 - Simpson's $\lambda$; $\mathrm{p}<0.01$ for BZCFs but insignificant for the control forest). This trend also indicates the conversion of natural mixed forests to the woodlands near the edges.

\subsection{Community Similarity and Dissimilarity between the Sites.} To demonstrate how the forest disturbances change the composition of the plant community as the distance gets closer to the human settlement areas, we determined similarity and dissimilarity between the sites. For Janajagaran BZCF, the maximum value of dissimilarity was 0.55 (similarity: $1-0.55$ $=0.45$ ) and the dissimilarity was between Site I versus Site VI and Site II versus Site VI. For Musharni Mai BZCF, the maximum value of dissimilarity was observed between Site I and Site VI (0.54) followed by Site I and Site V (0.42). 
TABLE 14: IVI of predominant species and Morisita Index of Dispersion in Parsa Wildlife Reserve.

\begin{tabular}{|c|c|c|c|c|c|c|c|}
\hline $\begin{array}{l}\text { Species } \\
\text { code }\end{array}$ & Name of the species & Site I & Site II & Site III & Site IV & Site V & Site VI \\
\hline 8 & Casearia graveolens Dalzell & $\begin{array}{c}16.20 \\
(1.2) \\
\end{array}$ & $\begin{array}{r}18.69 \\
(1.6) \\
\end{array}$ & $\begin{array}{c}12.30 \\
(1.3) \\
\end{array}$ & $\begin{array}{c}15.48 \\
(1.1) \\
\end{array}$ & $\begin{array}{l}4.96 \\
(1.8) \\
\end{array}$ & $\begin{array}{l}4.95 \\
(1.9) \\
\end{array}$ \\
\hline 4 & $\begin{array}{l}\text { Lagerstroemia parviflora } \\
\text { Roxb. }\end{array}$ & $\begin{array}{c}28.03 \\
(1.1) \\
\end{array}$ & $\begin{array}{l}35.81 \\
(1.2) \\
\end{array}$ & $\begin{array}{c}23.25 \\
(1.1) \\
\end{array}$ & $\begin{array}{c}18.65 \\
(1.3) \\
\end{array}$ & $\begin{array}{c}21.96 \\
(1.1) \\
\end{array}$ & $\begin{array}{c}15.84 \\
(1.2) \\
\end{array}$ \\
\hline 18 & $\begin{array}{c}\text { Miliusa velutina (Dunal) } \\
\text { Hook. f. \& Thoms. }\end{array}$ & $\begin{array}{c}12.59 \\
(1.6) \\
\end{array}$ & $\begin{array}{c}21.44 \\
(1.2) \\
\end{array}$ & $\begin{array}{c}14.03 \\
(1.3)\end{array}$ & $\begin{array}{l}13.12 \\
(1.2)\end{array}$ & $\begin{array}{c}24.42 \\
(1.3)\end{array}$ & $\begin{array}{l}17.11 \\
(1.3)\end{array}$ \\
\hline 46 & Phyllanthus emblica Linn. & $\begin{array}{l}6.00 \\
(3.0) \\
\end{array}$ & $\begin{array}{c}1.12 \\
(10.0)\end{array}$ & $\begin{array}{l}4.30 \\
(2.8)\end{array}$ & $\begin{array}{c}13.76 \\
(1.3)\end{array}$ & $\begin{array}{l}5.99 \\
(1.6)\end{array}$ & $\begin{array}{l}6.46 \\
(2.1)\end{array}$ \\
\hline 22 & Terminalia chebula Retz. & $\begin{array}{l}8.02 \\
(2.6) \\
\end{array}$ & $\begin{array}{l}6.92 \\
(1.4) \\
\end{array}$ & $\begin{array}{l}6.03 \\
(1.3) \\
\end{array}$ & $\begin{array}{c}0.99 \\
(10.0) \\
\end{array}$ & $\begin{array}{l}0.82 \\
(10) \\
\end{array}$ & \\
\hline 1 & Shorea robusta Gaertn. & $\begin{array}{c}101.09 \\
(1.4) \\
\end{array}$ & $\begin{array}{c}72.09 \\
(1.4) \\
\end{array}$ & $\begin{array}{c}90.43 \\
(1.3) \\
\end{array}$ & $\begin{array}{c}74.39 \\
(1.1) \\
\end{array}$ & $\begin{array}{l}72.41 \\
(1.3) \\
\end{array}$ & $\begin{array}{c}95.39 \\
(1.1) \\
\end{array}$ \\
\hline 27 & Dalbergia latifolia Roxb. & $\begin{array}{l}7.96 \\
(1.8) \\
\end{array}$ & $\begin{array}{l}9.03 \\
(1.2) \\
\end{array}$ & $\begin{array}{c}10.84 \\
(1.2) \\
\end{array}$ & $\begin{array}{l}6.87 \\
(1.8) \\
\end{array}$ & $\begin{array}{l}5.94 \\
(2.5) \\
\end{array}$ & $\begin{array}{l}6.92 \\
(1.4) \\
\end{array}$ \\
\hline 12 & Dillenia pentagyna Roxb. & $\begin{array}{c}13.24 \\
(1.8)\end{array}$ & $\begin{array}{c}19.78 \\
(1.3)\end{array}$ & $\begin{array}{c}15.85 \\
(1.8)\end{array}$ & $\begin{array}{c}12.75 \\
(1.5)\end{array}$ & $\begin{array}{l}6.58 \\
(2.1)\end{array}$ & $\begin{array}{l}4.57 \\
(2.3)\end{array}$ \\
\hline 21 & $\begin{array}{c}\text { Terminalia alata Heyne ex } \\
\text { Roth }\end{array}$ & $\begin{array}{r}13.69 \\
(1.5)\end{array}$ & $\begin{array}{l}15.55 \\
(1.9)\end{array}$ & $\begin{array}{l}11.17 \\
(1.2)\end{array}$ & $\begin{array}{c}10.55 \\
(1.7)\end{array}$ & $\begin{array}{l}12.71 \\
(1.2)\end{array}$ & $\begin{array}{c}13.78 \\
(1.5)\end{array}$ \\
\hline 2 & $\begin{array}{c}\text { Adina cordifolia (Willd. ex } \\
\text { Roxb.) Benth. \& Hook. f. ex } \\
\text { Brandis }\end{array}$ & $\begin{array}{l}10.12 \\
(1.8)\end{array}$ & $\begin{array}{l}1.66 \\
(4.7)\end{array}$ & $\begin{array}{l}5.00 \\
(1.7)\end{array}$ & $\begin{array}{l}8.17 \\
(2.1)\end{array}$ & $\begin{array}{l}9.97 \\
(1.9)\end{array}$ & $\begin{array}{c}13.95 \\
(2.1)\end{array}$ \\
\hline 13 & Syzygium cumini (L.) Skeels & $\begin{array}{l}5.67 \\
(2.1) \\
\end{array}$ & $\begin{array}{c}12.24 \\
(1.4) \\
\end{array}$ & $\begin{array}{l}7.78 \\
(1.3) \\
\end{array}$ & $\begin{array}{c}0.99 \\
(10.0) \\
\end{array}$ & $\begin{array}{c}0.81 \\
(10.0) \\
\end{array}$ & $\begin{array}{c}2.51 \\
(3.6) \\
\end{array}$ \\
\hline 47 & $\begin{array}{l}\text { Desmodium oojenense } \\
\text { (Roxb.) Ohashi }\end{array}$ & $\begin{array}{c}15.74 \\
(1.5)\end{array}$ & $\begin{array}{l}12.51 \\
(1.4)\end{array}$ & $\begin{array}{l}5.83 \\
(1.5)\end{array}$ & $\begin{array}{c}24.32 \\
(1.2)\end{array}$ & $\begin{array}{c}13.45 \\
(1.4)\end{array}$ & $\begin{array}{c}13.93 \\
(1.6)\end{array}$ \\
\hline 26 & $\begin{array}{c}\text { Anogeissus latifolius (Roxb. } \\
\text { ex DC.) Bedd. }\end{array}$ & $\begin{array}{l}8.07 \\
(2.3)\end{array}$ & $\begin{array}{l}7.92 \\
(1.5) \\
\end{array}$ & $\begin{array}{l}4.87 \\
(2.1) \\
\end{array}$ & $\begin{array}{c}13.34 \\
(1.5) \\
\end{array}$ & $\begin{array}{l}4.44 \\
(2.1) \\
\end{array}$ & $\begin{array}{c}10.80 \\
(1.3)\end{array}$ \\
\hline 48 & Garuga pinnata Roxb. & $\begin{array}{l}6.97 \\
(2.1) \\
\end{array}$ & $\begin{array}{l}8.47 \\
(2.3) \\
\end{array}$ & $\begin{array}{l}15.50 \\
(2.2) \\
\end{array}$ & $\begin{array}{l}7.70 \\
(3.7) \\
\end{array}$ & $\begin{array}{l}11.72 \\
(1.8) \\
\end{array}$ & $\begin{array}{l}13.53 \\
(1.4) \\
\end{array}$ \\
\hline 3 & $\begin{array}{c}\text { Lannea coromandelica } \\
\text { (Houtt.) Merr. }\end{array}$ & $\begin{array}{c}0.83 \\
(10.0) \\
\end{array}$ & $\begin{array}{l}2.63 \\
(5.5) \\
\end{array}$ & $\begin{array}{c}3.19 \\
(4.0) \\
\end{array}$ & $\begin{array}{c}3.51 \\
(3.4) \\
\end{array}$ & $\begin{array}{c}0.86 \\
(10.0) \\
\end{array}$ & $\begin{array}{l}11.21 \\
(1.4) \\
\end{array}$ \\
\hline 23 & Buchanania latifolia Roxb. & $\begin{array}{c}10.68 \\
(2.0) \\
\end{array}$ & $\begin{array}{l}9.14 \\
(1.6) \\
\end{array}$ & $\begin{array}{c}12.54 \\
(1.3) \\
\end{array}$ & $\begin{array}{l}11.12 \\
(1.5) \\
\end{array}$ & & $\begin{array}{l}0.67 \\
(10) \\
\end{array}$ \\
\hline 14 & $\begin{array}{l}\text { Dysoxylum gobara } \\
\text { (Buch.-Ham.) Merr. }\end{array}$ & $\begin{array}{l}1.95 \\
(5.4)\end{array}$ & $\begin{array}{l}1.62 \\
(4.9)\end{array}$ & & & $\begin{array}{c}22.96 \\
(1.2)\end{array}$ & $\begin{array}{l}4.36 \\
(3.9)\end{array}$ \\
\hline
\end{tabular}

TABLE 15: Index of similarity and dissimilarity among different sites for Janajagaran BZCF.

\begin{tabular}{|c|c|c|c|c|c|c|}
\hline & Site I & Site II & Site III & Site IV & Site V & Site VI \\
\hline Site I & & 0.74 & 0.82 & 0.68 & 0.57 & 0.45 \\
\hline Site II & 0.26 & & 0.85 & 0.67 & 0.59 & 0.45 \\
\hline Site III & 0.18 & 0.15 & & 0.71 & 0.67 & 0.52 \\
\hline Site IV & 0.32 & 0.33 & 0.29 & & 0.74 & 0.65 \\
\hline Site V & 0.43 & 0.41 & 0.33 & 0.26 & & 0.79 \\
\hline Site VI & 0.55 & 0.55 & 0.48 & 0.35 & 0.21 & \\
\hline
\end{tabular}

We observed similar trends for Radha Krishna BZCF with the highest dissimilarity between Site I and Site VI (0.59) followed by Site II and Site VI (0.49). Values showed the higher dissimilarity between the nearer plots and the farther plots in BZCFs. For PWR, the maximum dissimilarity was observed between Site II and Site VI, but the dissimilarity values across sites did not exceed 0.34 . The results indicated that dissimilarity values and their clustering heights were higher between the sites of BZCFs than the control forest sites in PWR (Figure 11, Appendix F, Tables 15-18).

NMDS was conducted to ordinate the sites based on the Bray-Curtis distance of IVI values of the species. The NMDS results showed that the sites of BZCFs were ordinated in the farther distances as compared to PWR forest (Figure 12). In 
TABLE 16: Index of similarity and dissimilarity among different sites for Musharni Mai BZCF.

\begin{tabular}{lcccccc}
\hline & Site I & Site II & Site III & Site IV & Site V & Site VI \\
\hline Site I & & $\mathbf{0 . 7 0}$ & $\mathbf{0 . 5 8}$ & $\mathbf{0 . 5 9}$ & $\mathbf{0 . 5 8}$ & $\mathbf{0 . 4 6}$ \\
\hline Site II & 0.30 & & $\mathbf{0 . 8 0}$ & $\mathbf{0 . 8 1}$ & $\mathbf{0 . 7 7}$ \\
\hline Site III & 0.42 & 0.20 & & & $\mathbf{0 . 8 7}$ & $\mathbf{0 . 8 5}$ \\
\hline Site IV & 0.41 & 0.19 & 0.13 & 0.15 & $\mathbf{0 . 7 0}$ \\
\hline Site V & 0.42 & 0.23 & 0.16 & 0.30 & 0.31 \\
\hline Site VI & 0.54 & 0.38 & 0.34 & & $\mathbf{0 . 6 7}$ \\
\hline
\end{tabular}

TABLE 17: Index of similarity and dissimilarity among different sites for Radha Krishna BZCF.

\begin{tabular}{lcccccc}
\hline & Site I & Site II & Site III & Site IV & Site V & Site VI \\
\hline Site I & & $\mathbf{0 . 7 5}$ & $\mathbf{0 . 6 7}$ & $\mathbf{0 . 6 4}$ & $\mathbf{0 . 5 3}$ & $\mathbf{0 . 4 1}$ \\
\hline Site II & 0.25 & & $\mathbf{0 . 8 0}$ & $\mathbf{0 . 7 8}$ & $\mathbf{0 . 9 0}$ & $\mathbf{0 . 7 6}$ \\
\hline Site III & 0.33 & 0.20 & & & 0.63 \\
\hline Site IV & 0.36 & 0.22 & 0.10 & 0.19 & $\mathbf{0 . 8 1}$ & \\
\hline Site V & 0.47 & 0.30 & 0.24 & 0.38 & 0.62 \\
\hline Site VI & 0.59 & 0.49 & 0.37 & & 0.69 \\
\hline
\end{tabular}

BZCFs, Site I and Site II ordinated in the farthest distances from Site VI reflecting a high variation in the species composition due to varying gradients of anthropogenic pressures. However, in case of PWR, the sites were clumped (ordinated in the shorter distances) in the central region of the ordinated axes. The ordination distances, however, do not correspond to the original distances among the sites.

\section{Discussion}

In this paper, we assessed how the changes in the ecological parameters in the $S$. robusta mixed forest are a function of the distance from the human settlements, and the interaction between anthropogenic disturbances and the forest management. The changes in the structure and composition were determined by comparing their values from the edge to the interior sites of the BZCFs and also with the control forest conditions in PWR.

We did not observe a significant pattern between total stem density and the distance from the settlements, but when density was segregated into species, the sum density of species other than S. robusta witnessed a significant positive pattern (Figure 3). Human activities such as collection of fuelwood (leading to an absence of coarse woody debris in BZCFs that was present in the forest stands of PWR), fodder, litter, and other forest products, as well as grazing animals, had reduced the density of woody species in the forests. But the decrease had been compensated (regardless of species-wise contribution) by the forest management interventions in the BZCFs. Therefore, in overall, we observed neither an increase nor a decrease in the total stem density while moving towards the forest interior from the edges. Changes in the spatial and temporal heterogeneity as a result of anthropogenic activities have also been assessed in several other studies [8-11, 38].

Considering the total basal area, we observed mixed results in the three forests while moving from the edge to the interior. Basal area was observed with a significant decreasing trend for Janajagaran BZCF, an insignificant decreasing trend for Musharni Mai BZCF, and an increasing trend for Radha Krishna BZCF (Figure 6) along the edge to the interior of the forests. Previous research also demonstrated similar results of no effect on the basal area with a distance from the human settlements [17]. In contrast, another study has shown that biomass (a parameter indicating basal area) is reduced in the forest edge relative to the interior [39]. Consistent with this result, the basal area of the species other than $S$. robusta increased with the distance from the forest edges (Figure 6). Based on \% basal area contributed, the forest edges were observed to have undergone biotic homogenization (S. robusta mixed stand to $S$. robusta stand) due to the disturbance and management interactions (Figure 6). The Ministry of Forests and Soil Conservation (MFSC) of Nepal has categorized the Sal (S. robusta) forest as a forest where $S$. robusta comprises more than $60 \%$ of the basal area and Sal Terai Mixed Hardwood Forest (STMH) as a forest where $S$. robusta comprises 33-60\% of the total basal area [40]. In case of BZCFs, the edges had more than $60 \%$ S. robusta basal area, a percentage not observed in the interior stands of BZCFs and the control forest; in the latter forests the percent contribution of S. robusta was between 33 and 60\% (Figure 7).

In our study, both Shannon-Wiener and 1 - Simpson's $\lambda$ diversity values showed a positive trend with the distance from the boundary lines of villages in BZCFs (Figures 9 and 10). But in PWR such a trend was not observed. Some primary studies have determined a clear pattern of change in diversity, richness, density, and basal area of the tree species towards the forest interior from the edges [12, 20, 41], whereas other studies have obtained contrasting results with more species richness and abundancy of heliophilic species in the forest edge than the interior [42-44].

The increasing value of species diversity with the distance from the settlements in our study strongly supports that human interventions (interaction of both management and 
TABLE 18: Index of similarity and dissimilarity among different sites for Parsa Wildlife Reserve.

\begin{tabular}{lcccccc}
\hline & Site I & Site II & Site III & Site IV & Site V & Site VI \\
\hline Site I & & $\mathbf{0 . 8 1}$ & $\mathbf{0 . 8 2}$ & $\mathbf{0 . 7 7}$ & $\mathbf{0 . 6 9}$ & $\mathbf{0 . 7 6}$ \\
\hline Site II & 0.19 & & $\mathbf{0 . 7 8}$ & $\mathbf{0 . 7 3}$ & $\mathbf{0 . 6 8}$ & $\mathbf{0 . 6 6}$ \\
\hline Site III & 0.18 & 0.22 & & & $\mathbf{0 . 6 9}$ & $\mathbf{0 . 7 1}$ \\
\hline Site IV & 0.23 & 0.27 & 0.25 & 0.29 & $\mathbf{0 . 7 4}$ \\
\hline Site V & 0.31 & 0.32 & 0.31 & 0.26 & 0.25 \\
\hline Site VI & 0.24 & 0.34 & 0.27 & & $\mathbf{0 . 7 5}$ \\
\hline
\end{tabular}

disturbances) have fostered a decrease in the richness and evenness of plant community and have changed the S. robusta mixed stands to pure $S$. robusta stands near the forest edges due to overexploitation of other plant species. Consistent with observations of intense monoculture-driven forest management nearby human settlements, other researchers have also posited that intensification of silviculture threatens species diversity $[45,46]$ and leads to the development of a community dominated by a single species or even-aged stands [47]. Anthropogenic pressures which lead to changes in the biological diversity are also responsible for changing the composition and stand quality of the forest ecosystems, microclimate, and nutrient cycling [48]. Increase in the generalist woody species can be the site of food sources, nest sites, and roosting sites for a variety of other species [49]. Higher plant diversity enhances the stability of the physical, chemical, and biotic properties of soils [50]. The intermediate disturbance hypothesis explains that diversity is maximum at the intermediate level of disturbance [51]. In contrast, species diversity declined with increasing level of disturbance in our study (Figures 9 and 10). There are also views reflecting that stability increases with the complexity of the ecosystems $[52,53]$. In addition, the similarity analysis between sites in $\mathrm{BZCF}$ reflected that there is a very little similarity between the sites in the edges compared to the interior (Figure 11). The result was also supported by NMDS outcomes (Figure 12). In the case of the control forest sites, such variation in the similarity was not observed.

Our study, based on the structural attributes, showed loosely defined community assemblages in the edges of BZCFs primarily due to the anthropogenic activities. In the long run, the existing inherent disturbances and ongoing management in the Terai $S$. robusta mixed forests can potentially lead to a decrease in the stability of the ecosystems. Natural forest areas that have been disturbed or altered to a large spatial extent or degree may not reach the similar structural complex (richness and composition) as primary forest [54]. In this context, fostering heterogeneity of the woody plant species is essential for sustainability.

\section{Conclusions}

Our results clearly indicated the effects of distance from human settlements on the vegetative attributes in the BZCFs. Maximum disturbance on the structural characteristics was observed near the edges which gradually decreased along the interior of the forests. The stands near the edges were under active management; however, a decrease in the richness and species diversity of the woody species was observed when moving from the edge to the interior. The management interventions in the forest sites near the settlements have directed the stands of BZCFs towards biotic homogenization and densification. These conditions cannot support habitat requirements of multiple species, and if the homogenization continues towards the interior of the BZCFs, it ultimately will impact the species diversity of the landscape. These situations of ecological changes due to intervention between anthropogenic disturbances and management practices should be assessed in larger spatial and regional scales to frame the future forest management strategies.

\section{Appendix}

\section{A. Predominant Species and Their Local Uses, and Geographical Location of the Sampled Sites}

See Tables 1 and 2 .

\section{B. Species Accumulation Curves}

The species accumulation curves for the BZCFs and Parsa Wildlife Reserve (control plot). The curves depend on the accumulation rates of new species over the increase in the sampling area. Comparatively more steep beginning rise of the curves showed that new species are increasing with addition of the sampling units. The accumulation rates of the new species in all forests were horizontal after the sampling area reached 1 ha (10 subplots each of $0.1 \mathrm{ha}$ ). This represents that $10,0.1$ ha plots are sufficient to represent the forest community at one site. See Figure 13.

\section{Community Structure of the Studied Forests}

See Tables 3, 4, 5, and 6 . 


\section{Importance Value Index (IVI) for Woody Plant Species in Each Site in the Studied Forests. The Total Value of IVI Is 300 Which Is the Sum of Relative Frequency, Relative Density, and Relative Basal Area Values}

See Tables 7, 8, 9, and 10 .

\section{E. IVI of Predominant Species and Morisita Index of Dispersion}

Predominant woody species and their Importance Value Index (IVI) for each site. Total of 12 species were found predominant in Janajagaran BZCF, 10 species in Musharni Mai BZCF, 11 species in Radha Krishna BZCF, and 17 species in Parsa Wildlife Reserve. Predominant species are considered high IVIs (IVI > 10). The values in parenthesis show Morisita's index $\left(\mathrm{I}_{\delta}\right)$ (a value of 1 indicates a random distribution, values $>1$ indicate clumped distribution, and values $<1$ indicate a uniform or regular distribution). Chisquared based probability shows that all the species showed clumped distribution (at critical level of 0.05) according to the distance from the boundary lines of villages (null hypothesis describes that the species have random distribution). See Tables 11, 12, 13, and 14.

\section{F. Similarity and Dissimilarity among Different Sites of the Studied Forests}

In the tables, the upper right section and the lower left section show similarity and dissimilarity values, respectively, between sites. See Tables 15, 16, 17, and 18.

\section{Data Availability}

The primary data used to support the findings of this study are included within the Appendix.

\section{Conflicts of Interest}

The authors declare that they have no conflicts of interest.

\section{Acknowledgments}

The authors are especially thankful to the forest user groups and administrations of Janajagaran BZCF, Musharni Mai BZCF, and Radha Krishna BZCF. The authors would also like to express their gratitude to the Department of National Parks and Wildlife Conservation and Office of Parsa Wildlife Reserve (recently designated as Parsa National Park), Nepal, for granting permission (letter reference numbers ECO335 - 2071/2072 and ECO074 - 2073/2074) to study the forests. They are thankful to National Herbarium and Plant Laboratories, Nepal, and Central Department of Botany, Tribhuvan University for the identification of plant specimens. The technical and field support from Wyoming Reclamation and
Restoration Center (WRRC), Amrit Campus, and Central Department of Environmental Science, Tribhuvan University, Nepal, is also thankfully acknowledged.

\section{References}

[1] D. Western, "Human-modified ecosystems and future evolution," Proceedings of the National Acadamy of Sciences of the United States of America, vol. 98, no. 10, pp. 5458-5465, 2001.

[2] C. Folke, S. Carpenter, B. Walker et al., "Regime shifts, resilience, and biodiversity in ecosystem management," Annual Review of Ecology, Evolution and Systematics, vol. 35, pp. 557581, 2004.

[3] D. U. Hooper, F. S. Chapin III, J. J. Ewel et al., "Effects of biodiversity on ecosystem functioning: A consensus of current knowledge," Ecological Monographs, vol. 75, no. 1, pp. 3-35, 2005.

[4] G. J. Nowacki and M. D. Abrams, "Is climate an important driver of post-European vegetation change in the Eastern United States?" GCB Bioenergy, vol. 21, no. 1, pp. 314-334, 2015.

[5] R. J. Morris, "Anthropogenic impacts on tropical forest biodiversity: A network structure and ecosystem functioning perspective," Philosophical Transactions of the Royal Society B: Biological Sciences, vol. 365, no. 1558, pp. 3709-3718, 2010.

[6] P. F. Hessburg and J. K. Agee, "An environmental narrative of Inland Northwest United States forests, 1800-2000," Forest Ecology and Management, vol. 178, no. 1-2, pp. 23-59, 2003.

[7] M. Sassen and D. Sheil, "Human impacts on forest structure and species richness on the edges of a protected mountain forest in Uganda," Forest Ecology and Management, vol. 307, pp. 206-218, 2013.

[8] J. Kouki, S. Löfman, P. Martikainen, S. Rouvinen, and A. Uotila, "Forest fragmentation in Fennoscandia: Linking habitat requirements of wood-associated threatened species to landscape and habitat changes," Scandinavian Journal of Forest Research, vol. 16, no. 1, pp. 27-37, 2001.

[9] M. J. Lawes, B. C. C. Lamb, and S. Boudreau, "Area- but no edgeeffect on woody seedling abundance and species richness in old Afromontane forest fragments," Journal of Vegetation Science, vol. 16, no. 4, pp. 363-372, 2005.

[10] C. M. Tucker, J. C. Randolph, T. Evans, K. P. Andersson, L. Persha, and G. M. Green, "An approach to assess relative degradation in dissimilar forests: Toward a comparative assessment of institutional outcomes," Ecology and Society, vol. 13, no. 1, 2008.

[11] T. G. Wade, K. Riitters, J. D. Wickham, and K. B. Jones, "Distribution and causes of global forest fragmentation," Conservation Ecology, vol. 7, no. 2, pp. 1-16, 2003.

[12] K. Majumdar and B. K. Datta, "Effects of anthropogenic disturbances on vegetation diversity and structure: A case study in the remnant forests surrounding the village ecosystems of Tripura, Northeast India," Chinese Journal of Population Resources and Environment, vol. 13, no. 4, pp. 332-340, 2015.

[13] S. R. Biswas and A. U. Mallik, "Species diversity and functional diversity relationship varies with disturbance intensity," Ecosphere, vol. 2, no. 4, 2011.

[14] J. Kimmins, Forest Ecology: A Foundation for Sustainable Forest Management and Environmental Ethics in Forestry, Prentice Hall, New Jersey, NJ, USA, 2004.

[15] E. L. Webb and R. N. Sah, "Structure and diversity of natural and managed sal (Shorea robusta Gaertn.f.) forest in the Terai 
of Nepal," Forest Ecology and Management, vol. 176, no. 1-3, pp. 337-353, 2003.

[16] I. P. Sapkota, M. Tigabu, and P. C. Odén, "Spatial distribution, advanced regeneration and stand structure of Nepalese Sal (Shorea robusta) forests subject to disturbances of different intensities," Forest Ecology and Management, vol. 257, no. 9, pp. 1966-1975, 2009.

[17] A. Popradit, T. Srisatit, S. Kiratiprayoon et al., "Anthropogenic effects on a tropical forest according to the distance from human settlements," Scientific Reports, vol. 5, Article ID 14689, 2015.

[18] K. B. Shrestha, I. E. Måren, E. Arneberg, J. P. Sah, and O. R. Vetaas, "Effect of anthropogenic disturbance on plant species diversity in oak forests in Nepal, Central Himalaya," International Journal of Biodiversity Science, Ecosystem Services \& Management, vol. 9, no. 1, pp. 21-29, 2013.

[19] S. Thapa and D. S. Chapman, "Impacts of resource extraction on forest structure and diversity in Bardia National Park, Nepal," Forest Ecology and Management, vol. 259, no. 3, pp. 641-649, 2010.

[20] D. S. Kacholi, "Edge-interior disparities in tree species and structural composition of the kilengwe forest in morogoro region, Tanzania," ISRN Biodiversity, vol. 2014, Article ID 873174, 8 pages, 2014.

[21] CBD, Nepal Fourth National Report to the Convention on Biological Diversity, Singha Durbar, Kathmandu, Nepal, 2009.

[22] K. A. Brown, D. F. B. Flynn, N. K. Abram, J. C. Ingram, S. E. Johnson, and P. Wright, "Assessing natural resource use by forest-reliant communities in madagascar using functional diversity and functional redundancy metrics," PLOS ONE, vol. 6, no. 9, 2011.

[23] G. Eilu, D. L. N. Hafashimana, and J. M. Kasenene, "Density and species diversity of trees in four tropical forests of the Albertine rift, western Uganda," Diversity and Distributions, vol. 10, no. 4, pp. 303-312, 2004.

[24] S. B. Jennings, N. D. Brown, and D. Sheil, "Assessing forest canopies and understorey illumination: Canopy closure, canopy cover and other measures," Forestry, vol. 72, no. 1, pp. 59-73, 1999.

[25] R. Bivand, C. Rundel, E. Pebesma, R. Stuetz, and K. O. Hufthammer, "Package "rgeos." R Packag. version 0.3-26," 2017.

[26] H. Nguyen, D. Lamb, J. Herbohn, and J. Firn, "Designing mixed species tree plantations for the tropics: Balancing ecological attributes of species with landholder preferences in the Philippines," PLoS ONE, vol. 9, no. 4, 2014.

[27] B. Husch, T. Beers, and J. Kershaw, Forest Mensuration, Wiley, New York, NY, USA, 2003.

[28] A. C. Newton, Forest Ecology and Conservation, Oxford University Press Inc., New York, NY, USA, 2007.

[29] C. E. Shannon, "A mathematical theory of communication," Bell Labs Technical Journal, vol. 27, pp. 379-423, 1948.

[30] E. H. Simpson, "Measurement of diversity," Nature, vol. 163, article no. $688,1949$.

[31] J. Oksanen, F. G. Blanchet, R. Kindt et al., "Vegan: Community Ecology Package," R Packag. ver. 2.4-3, 2017.

[32] E. A. Peña and E. H. Slate, "Global validation of linear model assumptions," Journal of the American Statistical Association, vol. 101, no. 473, pp. 341-354, 2006.

[33] H. Wolda, "Similarity indices, sample size and diversity," Oecologia, vol. 50, no. 3, pp. 296-302, 1981.

[34] M. Morisita, "I-Index, a measure of dispersion of individuals," Researches on Population Ecology (Kyoto), vol. 4, pp. 1-7, 1962.
[35] J. R. Bray and J. T. Curtis, "An ordination of the upland forest communities of southern wisconsin," Ecological Monographs, vol. 27, no. 4, pp. 325-349, 1957.

[36] P. R. Minchin, "An evaluation of the relative robustness of techniques for ecological ordination," Plant Ecology, vol. 69, no. 1-3, pp. 89-107, 1987.

[37] R Core Team R, "A language and environment for statistical computing," 2016.

[38] E. Ritter and D. Dauksta, "Human-forest relationships: Ancient values in modern perspectives," Environment, Development and Sustainability, vol. 15, no. 3, pp. 645-662, 2013.

[39] R. Chaplin-Kramer, I. Ramler, R. Sharp et al., "Degradation in carbon stocks near tropical forest edges," Nature Communications, vol. 6, 2015.

[40] DFRS, Terai Forests of Nepal (2010-2012), Kathmandu, Babarmahal, 2010.

[41] J. A. Sayer and T. C. Whitmore, "Tropical moist forests: Destruction and species extinction," Biological Conservation, vol. 55, no. 2, pp. 199-213, 1991.

[42] J. W. Ranney, M. C. Bruner, and J. B. Levenson, "The Importance of Edge in the Structure and Dynamics of Forest Islands," in Forest Island Dynamics in Man-Dominated Landscapes, R. L. Burgess and D. M. Sharp, Eds., pp. 67-95, Springer-Verlag, New York, NY, USA, 1981.

[43] B. J. Palik and P. G. Murphy, "Disturbance versus edge effects in sugar-maple/beech forest fragments," Forest Ecology and Management, vol. 32, no. 2-4, pp. 187-202, 1990.

[44] S. Fraver, "Vegetation responses along edge-to-interior gradients in the mixed hardwood forests of the roanoke river basin, North Carolina," Conservation Biology, vol. 8, no. 3, pp. 822-832, 1994.

[45] K. J. Puettmann, K. D. Coates, and C. Messier, A Critique of Silviculture, Island Press, Washington, USA, 2009.

[46] J.-M. Carnus, J. Parrotta, E. Brockerhoff et al., "Planted forests and biodiversity," Journal of Forestry, vol. 104, no. 2, pp. 65-77, 2006.

[47] E. May, At the Cutting Edge: The Crisis in Canada's Forests, Key Porter Books, Toronto, Ontario, 2005.

[48] M. Kappelle, P. A. F. Kennis, and R. A. J. de Vries, "Changes in diversity along a successional gradient in a Costa Rican upper montane Quercus forest," Biodiversity and Conservation, vol. 4, no. 1, pp. 10-34, 1995.

[49] C. Martínez-Garza and H. F. Howe, "Restoring tropical diversity: Beating the time tax on species loss," Journal of Applied Ecology, vol. 40, no. 3, pp. 423-429, 2003.

[50] M. Pohl, D. Alig, C. Körner, and C. Rixen, "Higher plant diversity enhances soil stability in disturbed alpine ecosystems," Plant and Soil, vol. 324, no. 1, pp. 91-102, 2009.

[51] R. Abugov, "Species diversity and phasing of disturbance," Ecology, vol. 63, no. 2, pp. 289-293, 1982.

[52] M. I. Shafi and G. A. Yarranton, "Diversity, floristic richness, and species evenness during a secondary (post-fire) succession," Ecology, vol. 54, no. 4, pp. 897-902, 1973.

[53] E. G. Leigh, "On the relation between the productivity, biomass, diversity, and stability of a community," Proceedings of the National Acadamy of Sciences of the United States of America, vol. 53, no. 4, pp. 777-783, 1965.

[54] R. L. Chazdon, C. A. Peres, D. Dent et al., "The potential for species conservation in tropical secondary forests," Conservation Biology, vol. 23, no. 6, pp. 1406-1417, 2009. 

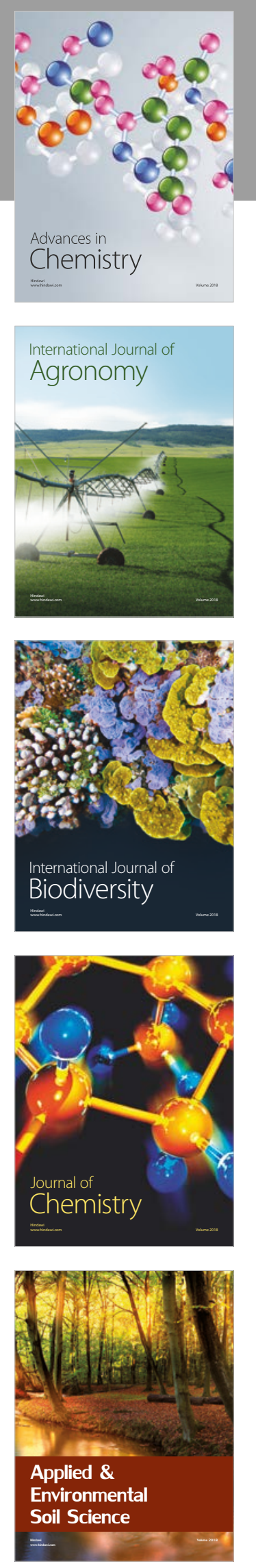

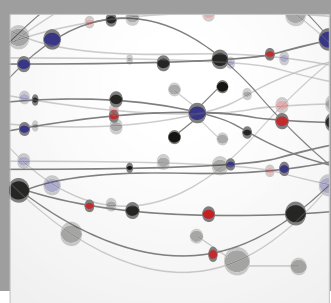

The Scientific World Journal

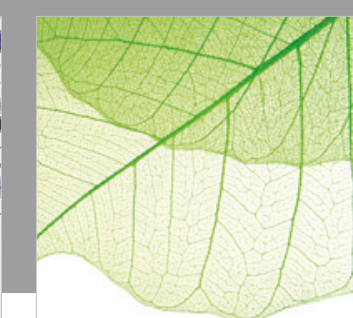

Journal of Botany

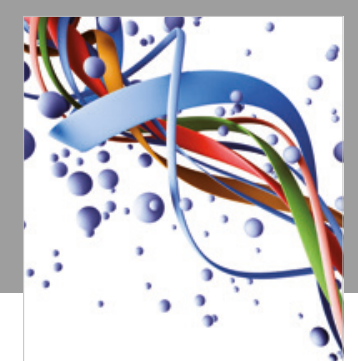

Scientifica

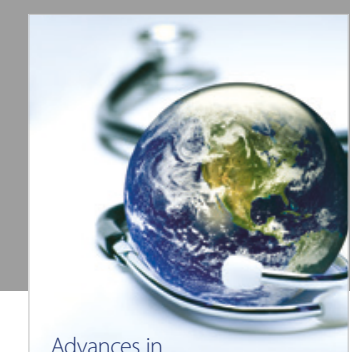

Public Health

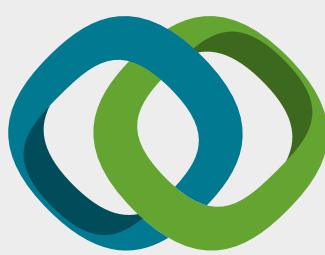

Hindawi

Submit your manuscripts at

www.hindawi.com
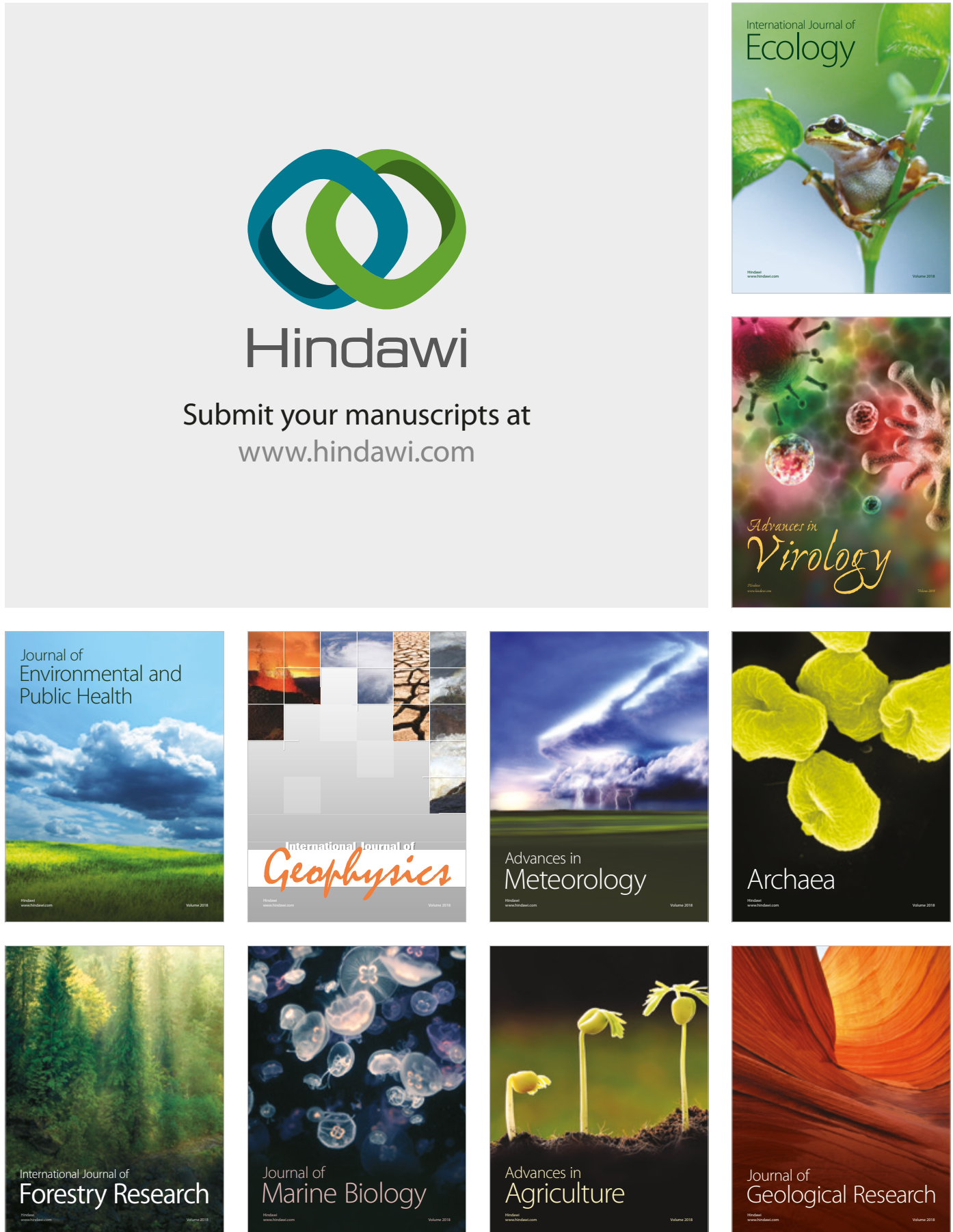

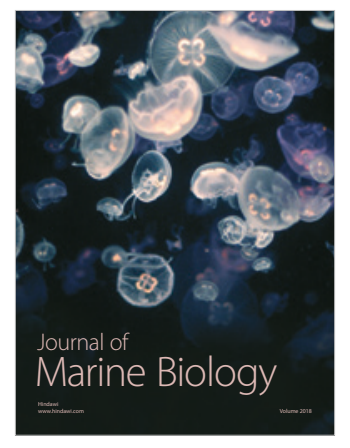

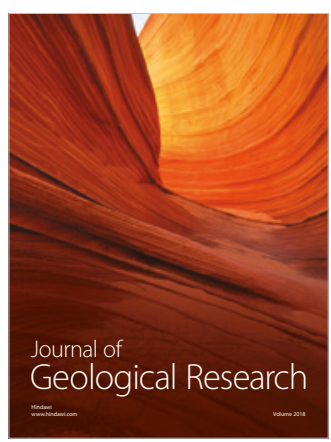

